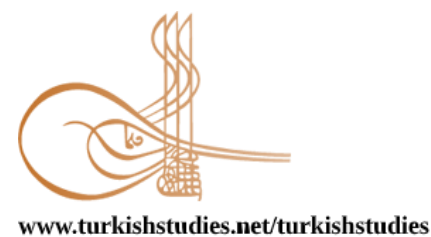

Turkish Studies

eISSN: $1308-2140$

Research Article / Araștırma Makalesi

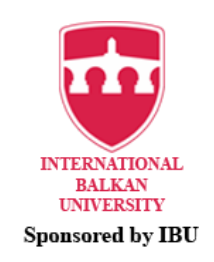

\title{
Geç Osmanlı Dönemi Mimarisi’nden Bir Temsil: Ankara Sanayi Mektebi
}

\author{
An Example of the Late Ottoman Period Architecture: Ankara Industry School
}

\author{
Kübra Çeber*
}

\begin{abstract}
This study is about the Ankara Industry School, one of the industry, education, and architecture developments during the Ottoman modernization process. The school, which opening date is unknown and was first mentioned as a youth detention center in the 1872 almanac of Ankara, is a vocational education institution essentially aimed at taking in poor and orphaned boys and teaching them a profession. A new building was built for the Ankara Industry School, which foundations were laid in 1901 and which operated in various facilities for rent in its initial phase. With its administration-classroom structure and workshops surrounding the inner courtyard from three directions, the school, which is one of the first examples of zoning focused on Bankalar Street with the Late Ottoman Period, was able to provide education and accommodation for its students under one roof. This study aims to introduce the design understanding and architectural features of Ankara Industry School, to demonstrate the school's role in the process of change in Ankara, and to evaluate it in the context of its period-typical features by comparing it to other industrial schools and contemporary educational structures in the context of architecture. As a result of the study, it was found that Ankara Industry School, with all its characteristics, contributes to the references of its time. It was underlined that the school had an important place in the identity of the city of Ankara, which has transformed from a small town into the capital of Turkey. The uncertainty in the construction process of Ankara Industry School illustrates the impact of the educational model of industrial schools on the design of the space, the identity of the architect, and the problem of the premise between the building and the layout plan of 1911 . The impact of the simplified Neo-Renaissance style in the school's design concept was seen, and it was concluded that the school was a pioneer in the 1911 layout plan due to the discussions. Moreover, it should be pointed out that the construct and the planning scheme of the school, which have survived until today without losing their function and originality, have been taken as an example and interpreted in vocational schools that train in different fields in the Republican Period.
\end{abstract}

Structured Abstract: One institution that plays a leading role in developing our history of vocational education is the art schools. These schools' origins, which continue today under the name of Anatolian Vocational High School, dating back to the Ottoman modernization process. By the 19th century, vocational education provided by ahi-order and guild organizations transformed part of industrialization efforts in the Ottoman modernization process. The opening of new factories by the industrialization movements, particularly in İstanbul, necessitated the training of qualified personnel to enter new lines of business. Industrial schools, established to train qualified personnel to work in modern industry, are vocational education that breaks away from tradition and is included in school programs as part of the educational

\footnotetext{
* Sanat Tarihi Uzman1,

Art Historian

ORCID 0000-0002-1045-7624

ceberkubra7@gmail.com Studies, 16(7), 65-84. https://dx.doi.org/10.7827/TurkishStudies.52912

Received/Geliş: 12 October/Ekim 2021

Accepted/Kabul: 27 December/Aralık 2021

Published/Yayın: 31 December/Aralık 2021

Checked by plagiarism software

CC BY-NC 4.0
}

Cite as/ Atıf: Çeber, K. (2021). Geç Osmanlı dönemi mimarisi'nden bir temsil: Ankara Sanayi Mektebi. Turkish 
system. The establishment of industrial schools began with the Nis reformatory, opened in 1863 by Mithat Pasha. The youth detention centers, which spread first in the Balkans and then in the Anatolian lands, were transformed into industrial schools from 1882. These schools, transferred to the Republican Period under the name of art schools, continued to develop within the educational and industrial policies of the time.

Over time, the development of industrial schools resulted in the emergence of industrial school buildings, which found a position among the new types of buildings in Late Ottoman architecture. In the administrative-classroom buildings of the industrial schools, a floor plan scheme with rooms arranged along the corridor was used. For the workshops where vocational practices are carried out, structures are designed to provide students with a comfortable work environment. The industrial schools that managed to survive from the Ottoman Empire to the Republic and were transferred to the Ministry of National Education in 1927 are listed according to their date of establishment as İzmir Industry School (1882), Edirne Industry School (1895), İstanbul Industry School (1899), Bursa Industry School (1899), Diyarbakır Industry School (1900), Konya Industry School (1901), Ankara Industry School (1901-) and Kastamonu Industry School. Except for the Konya Industry School and Kastamonu Industry School, which were built in the First National Architectural Style, these school buildings, built after the opening of Sanayi Nefise Mektebi, were designed in the Neo-Renaissance style, which is one of the preferred styles in public and civil buildings of Late Ottoman Period architecture. In 1911, the Department of Commerce and Public Works published a design plan for the newly built or structurally obsolete industrial schools that is remarkable for our architectural history. The construction of Ankara Industry School, which began in 1901, was not yet completed, and Kastamonu Industry School was not yet built when this type of project consisted of a two-story administrative classroom building and a one-story building surrounding a rectangular inner courtyard on three sides published.

Ankara Industry School, which is the subject of this article, is a vocational school founded in the process and is one of the elements that make up the industrial history of Ankara. Ankara Industry School, which opening date is unknown and first mentioned in the 1872 Almanac of Ankara as a youth detention center, is an educational institution designed to accommodate mainly poor and orphaned boys and teach them a profession. A new building, begun in 1901 and completed before 1924, was built for Ankara Industry School, which operated in rental buildings in its early days. With its structure of administrative rooms and workshops surrounding the inner courtyard from three directions, the school, which is one of the first examples of development-oriented to Bankalar Street during the Late Ottoman Period, was able to offer its students education and housing under one roof. The school, which could give its name to the street on which it was located at the time of its construction, is the only educational building in the center of Ulus that maintained the same function from the Ottoman Empire to the Republic.

This study focus on the design concept and architectural features of Ankara Industrial School. In this context, the first part of the study, which focuses on the architectural characteristics of the Ankara Industry School, explains the transformation of vocational education at the Ankara Industry School, and the second part discusses the design approach and architectural features of the school. In the evaluation and conclusion part of this study, the contribution of Ankara Industry School to the history of Ankara is mentioned, as is the uncertainty in the school's construction process, the identity of its architect, and the problem of precedence between it and the 1911 layout plan. Ankara Industrial School was examined in the architectural understanding of the time compared to other industrial schools and their contemporary educational structures. This study concludes that Ankara Industry School is an important vocational training institution that reflects the Late Ottoman Period with all its characteristics. It was underlined that the school has an important place in the history of Ankara, which has transformed from a small town into capital, both with its educational function and its architectural structure. It is mentioned that the building, exemplary of how modernizing vocational education has shaped architecture, has largely preserved its originality, although it has been subjected to some misapplications in the process. It turned out that the school, whose design concept shows the effects of the simplified neo-Renaissance style, was the predecessor of the 1911 layout plan, which was very early for creating type plans in our country. Furthermore, the similarities of Ankara Industry School with some vocational schools from the Early Republican Period were identified in terms of design and plan scheme. In this context, it is aimed to emphasize that Ankara Industry School had the qualifications to address the needs of schools providing vocational education services in various periods and areas.

Keywords: Art History, Vocational Education, Educational Structures, Late Ottoman Architecture, Ankara Industry School.

Turkish Studies, 16(7) 
Öz: Bu çalışma Osmanlı modernleşmesi sürecinde sanayi, eğitim ve mimari alanında meydana gelen gelişmeler içerisinde yer alan Ankara Sanayi Mektebi'ni konu edinmektedir. Açılış tarihi bilinmeyen ve ilk kez 1872 tarihli Ankara kent yıllığında 1slahhane olarak bahsedilen mektep, temelde fakir ve kimsesiz erkek çocukların barındırılıp onlara bir meslek dalının öğretilmesini amaç edinmiş bir mesleki eğitim kurumudur. Erken dönemlerinde çeşitli yapılarda kiralık olarak faaliyet gösteren Ankara Sanayi Mektebi için temelleri 1901 yılında atılan yeni bir yapı inşa edilmiştir. Geç Osmanlı Dönemi’yle birlikte Bankalar Caddesi’nde yoğunlaşan imar faaliyetlerinin ilk örnekleri arasında yer alan mektep, yönetim-derslik yapısı ile iç avluyu üç yönden çevreleyen atölyeleriyle öğrencilerine eğitim ve barınma hizmetlerini tek çatı altına sunabilmiştir. Çalışmanın amacı; Ankara Sanayi Mektebi'nin tasarım anlayışı ve mimari özelliklerini tanıtmak, mektebin Ankara'nın değişim sürecindeki rolünü göstermek, mimari özellikleri ile onu diğer sanayi mektepleri ve çağdaşı olan eğitim yapılarıyla karşılaş̧ırarak dönem özellikleri kapsamında değerlendirmektir. Çalışma sonucunda Ankara Sanayi Mektebi'nin bünyesinde barındırdığı tüm özellikleriyle döneminin referanslarına katk1 sağladığı görülmüştür. Küçük bir kasabadan Türkiye'nin başkentine dönüşen Ankara'nın kent kimliğinde mektebin hem işlevi hem de tarihi yapısıyla önemli bir yer teşkil ettiğinin altı çizilmiştir. Sanayi mekteplerine ait eğitim modelinin mekanı biçimlendirme üzerindeki etkisini örnekleyen Ankara Sanayi Mektebi’nin yapım sürecindeki belirsizlik, mimarının kimliği ve yapının 1911 tertibat planı ile arasındaki öncüllük sorunsalı üzerinde tartışılmışı̧ır. Tasarım anlayış̧ıla sadeleştirilmiş neo-Rönesans üslubuna referans veren mektebin, tartışmalar sonucunda 1911 tertibat planına öncül olduğu sonucu ortaya koyulmuştur. Bunlara ek olarak işlevini ve özgünlüğü kaybetmeden günümüze kadar gelebilen mektebin kurgu ve plan şemasının, Cumhuriyet Dönemi'nde çeşitli alanlarda eğitim veren meslek okullarında örnek alınıp yorumlanmış olmasına da dikkat çekilmek istenilmiş̧ir.

Anahtar Kelimeler: Sanat Tarihi, Mesleki Eğitim, Eğitim Yapıları, Geç Osmanlı Dönemi Mimarlığı, Ankara Sanayi Mektebi.

\section{Giriş}

Kuruluşundan itibaren kendine özgü kurumlarıyla güçlü bir devlet olarak varlığını sürdüren Osmanlı Devleti, savaş yenilgilerinin ardından gelen toprak kayıplarıyla Batı'nın üstünlüğünü kabul ederek Osmanlı modernleşmesi adı verilen bir değişim ve yenilik sürecine girmiştir. Öncelikle askeri alanda görülen modernleşme süreci Tanzimat'ın ilanıyla birlikte; idari, siyasi, hukuki, sanayi, mimari, eğitim ve bireyin günlük hayatına kadar uzanan alanları dahi etkilemiştir. Modernleşme sürecinin sanayi ve eğitim alanındaki yansıması olarak değerlendirilen sanayi mektepleri, yıllarca ahilik ve lonca teşkilatlarınca yürütülen meslek eğitiminin geleneksellikten çıkartılarak eğitim sisteminin bir parçası haline gelmiş şeklidir. Eğitim sisteminin bir parçası olan ve bu alanda uygulamaya konulan modernleşme projesi ile sanayi mekteplerinde okuyan öğrencilerin hem pratik yaparak meslek eğitimi almaları hem de nitelikli birer eleman olarak üretime katkı sağlamaları amaçlanmıştır.

1863 yılından itibaren faaliyet göstermeye başlayan islahhaneler sanayi mekteplerinin temeli kabul edilirken, 1868 yılında eğitim vermeye başlayan İstanbul Sanayi Mektebi ise açılacak olan diğer sanayi mekteplerinin öncülü olmuştur. Sanayi eğitimi hem sslahhaneler hem de sanayi mektepleri üzerinden verilirken, bu ikili sisteme devlet tarafindan yeni bir düzenleme getirilmiștir. Yeni düzenlemeyle 1882 yılindan itibaren mevcut tüm 1slahhaneler sanayi mekteplerine dönüştürülmüş böylece sanayi eğitiminin tek çatı altında devam ettirilmesi sağlanmıştır. Meslek eğitiminin sanayi mektepleri üzerinden yürütülmeye başlamasının ardından, 1slahhane olarak kullanılan mevcut kiralık binalar zamanla artan meslek dalları ve öğrenci sayıları karşısında yetersiz kalmıştır. Bu yetersizlik Geç Osmanlı Dönemi mimarisinin yeni yapı türleri içerisinde yerini alan sanayi mekteplerine ait yapıların ortaya çıkmasını sağlamıştır ${ }^{1}$.

Sanayi mektepleri uygulamalı nitelik taşıyan eğitim programlarına uygun olacak şekilde, yönetim-derslik yapısı ve atölye yapılarından oluşan bir yapı topluluğu olarak inşa edilmiştir.

${ }^{1}$ Geç Osmanlı Dönemi mimarisinin yeni yapı türleri hakkında detaylı bilgi için bkz. Kuban, 2007, s.661-672. 
Sanayi mekteplerinin yönetim-derslik yapılarında, koridor boyunca yerleştirilmiş mekanlara sahip plan şeması kullanmıştır. Meslek uygulamalarının yapıldığı atölyeler için ise öğrencilere rahat çalışma imkanı sunabilecek yapılar tasarlanmıştır. Osmanlı'dan Cumhuriyet'e ayakta kalmayı başarabilen ve 1927 yılında Milli Eğitim Bakanlığı'na devredilmiş sanayi mektepleri inşa tarihlerine göre; İzmir Sanayi Mektebi (1882), Edirne Sanayi Mektebi (1895), İstanbul Sanayi Mektebi (1899), Bursa Sanayi Mektebi (1899), Diyarbakır Sanayi Mektebi (1900), Konya Sanayi Mektebi (1901), Ankara Sanayi Mektebi ve Kastamonu Sanayi Mektebi (1916) olarak sıralanmaktadır. Sanayi Nefise Mektebi'nin açılışı ardından inşa edilen bu mektep yapılarının, Birinci Ulusal Mimarlık Üslubu ${ }^{2}$ ile inşa edilen Konya Sanayi Mektebi ve Kastamonu Sanayi Mektebi hariç, Geç Osmanlı Dönemi kamu yapılarının mimari özelliklerini yansıttıkları görülmektedir. 1911 yılına gelindiğinde yeni yapılacak ya da fiziki açıdan elden geçirilecek olan sanayi mektepleri için Ticaret ve Nafia Nezareti tarafından mimarlık tarihimiz açısından dikkat çeken bir tertibat planı yayınlanmıştır (Yıldırım, 2012, s.168) (Resim 1).

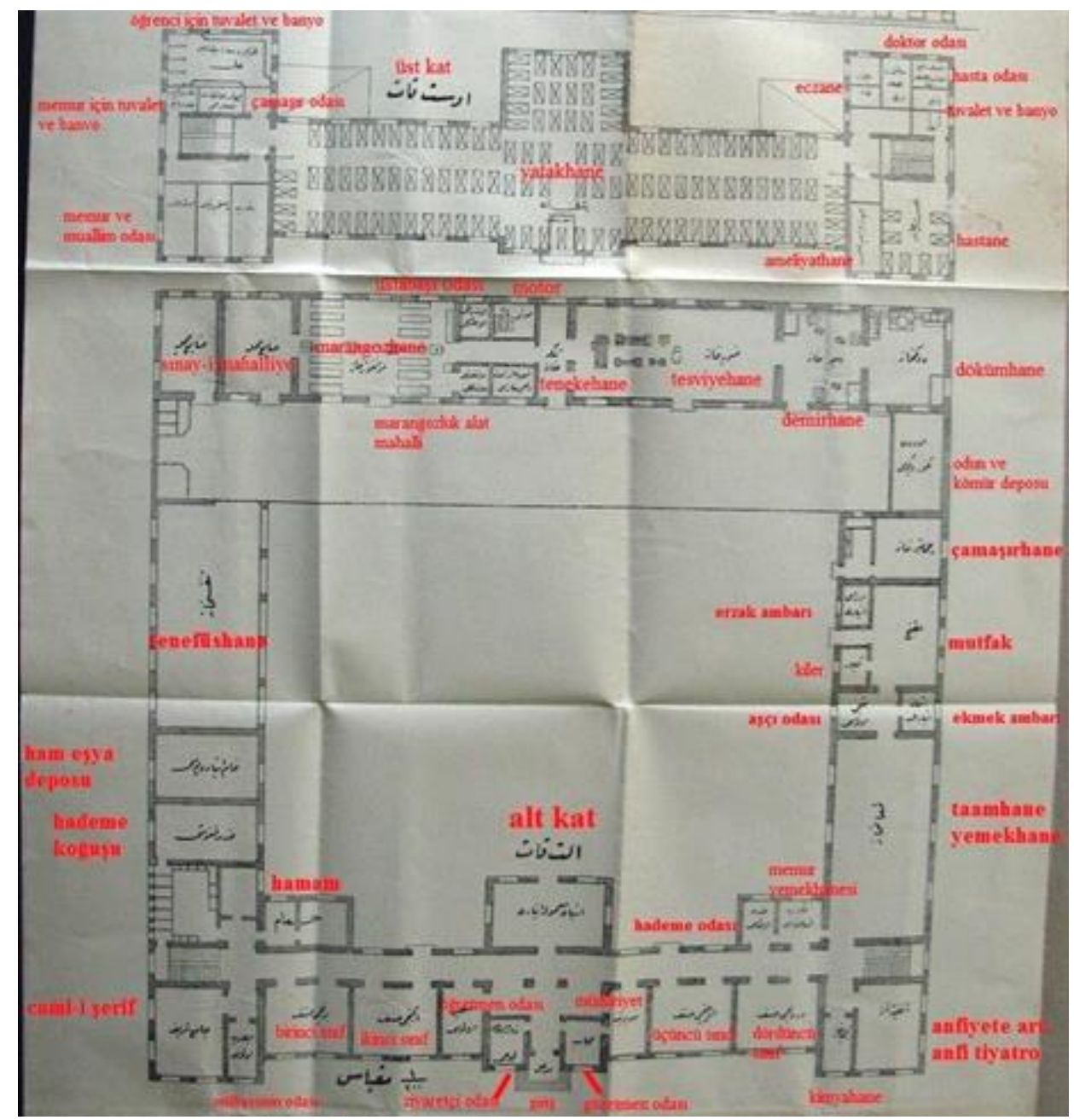

Resim 1: Ticaret ve Nafia Nezareti tarafindan hazırlanan tertibat planı (Yıldırım, 2012, s.168)

\footnotetext{
${ }^{2}$ Birinci Ulusal Mimarlık üslubu hakkında ayrıntılı bilgi için bkz. Aslanoğlu, 2010, s.17-99.
} 
1/200 ölçeğinde hazırlanmış tertibat planı, iki katlı yönetim-derslik yapısı ve dikdörtgen planlı iç avluyu üç yönden çevreleyen tek katlı yapılarından oluşmaktadır. Yönetim derslik yapısının zemin katı eğitim birimleri için, birinci katı ise yatakhane ve sağlık birimleri için düzenlenmiştir. Yönetim-derslik yapısının karşısındaki kol tamamen atölye yapısı olarak tasarlanmıştır. Marangozhane, tesviyehane, demirhane, dökümhane ve tenekehaneye ait uygulama alanlarından oluşan bu kolun orta aksında ustabaşı odası ve meslek dallarına ait hizmet birimleri yer almaktadır. Avluyu çevreleyen diğer iki kol ise tenefüshane, yemekhane ve hademe koğuşu gibi çeşitli hizmet birimlerince kullanılmak için planlanmıştır.

1911 tertibat planı yayınlandığında Ankara Sanayi Mektebi’nin 1901 yılında başlayan yapım süreci tamamlanmamış, Kastamonu Sanayi Mektebi ise henüz inşa edilmemiştir. Ankara Sanayi Mektebi ile 1911 tertibat planı aynı boyuta getirilip karşılaştırıldığında plan şemaları ile ana duvar ve açıklıkların büyük ölçüde örtüştükleri tespit edilmiştir. Ülkemizde tip plan üretilmesi için erken bir tarih olan 1911 y1lında hazırlanan bu tertibat planıyla Ankara Sanayi Mektebi'nin örtüşmesi onu sanayi mektepleri arasında dikkat çekici kılmaktadır.

Ulus'un merkezinde Osmanlı'dan Cumhuriyet'e aynı işlevi sürdürebilmiş tek eğitim yapısı olan Ankara Sanayi Mektebi'nin tasarım anlayışı ve mimari özelliklerine odaklanan bu çalışmanın ${ }^{3}$ birinci bölümünde; meslek eğitiminin geçirdiği dönüşüm Ankara Sanayi Mektebi üzerinden anlatılmış, ikinci bölümde ise mektebin tasarım anlayışı ele alınmıştır. Çalışmanın değerlendirme ve sonuç bölümünde; Ankara Sanayi Mektebi'nin değişim sürecindeki Ankara'ya sağladığı katkılar üzerinde durulmuş, mektebin mimarının kimliği ve 1911 tertibat planı ile arasındaki öncüllük sorunsalı üzerine tartışılmış, döneminin mimari anlayışı bağlamında değerlendirilen mektep diğer sanayi mektepleri ve çağdaşı olan eğitim yapılarıyla karşılaştırılmıştır.

\section{Ankara Sanayi Mektebi'nin Kuruluş ve Gelişim Süreci}

Ankara Sanayi Mektebi, temelde fakir ve kimsesiz erkek çocuklarının barındırılıp onlara bir meslek dalının öğretilmesi amacıyla kurulmuş bir meslek okuludur. Kesin açılış tarihi bilinmeyen ve ilk olarak 1872 yılına ait Osmanlı kent yıllıklarında 1slahhane olarak bahsedilen mektep, 1876 yılında sanayi mektebine dönüştürülmüştür (Koç, 2014, s.42; Keskin, 2016, s.65; Altıntaş, 2016, s.146).

1878 yılından yüzyıl sonuna kadar faaliyette olduğuna dair bilgisine rastlanılmayan ve diğer sanayi mektepleri gibi kiralık yapılarda eğitim veren Ankara Sanayi Mektebi için Ulus'ta yeni bir yapı inşa edilmesi kararı alınmıştır. Temelleri 1901 yılında atılan mektebin maddi imkansızlıklar nedeniyle inşaatı 1909 yılında durdurulmuş, yarım kalan inşaata ise ancak 1915 yılında başlanılmıştır (Keskin, 2016, s.74). Uzun süren inşa sürecinin kesin olarak ne zaman tamamlandığı arşiv belgelerinde belirtilmemiş olsa da 1924 tarihli Ankara Şehri Haritası'nda mektebin tamamlanmış olarak yer alması bu sürecin 1924 tarihinden önceki bir zamanda sonlandığına işaret etmektedir (Resim 2-3).

\footnotetext{
${ }^{3}$ Bu makale, Hacettepe Üniversitesi Sanat Tarihi Programı'nda Öğr. Gör. Dr. Çiler Buket Tosun yürütücülüğünde tamamlanmış olan Osmanlı Modernleşmesi Sürecinde Sanayi Mektepleri Bağlamında Ankara Sanayi Mektebi adlı yükssek lisans tezinden (2017) derlenmiştir.
} 


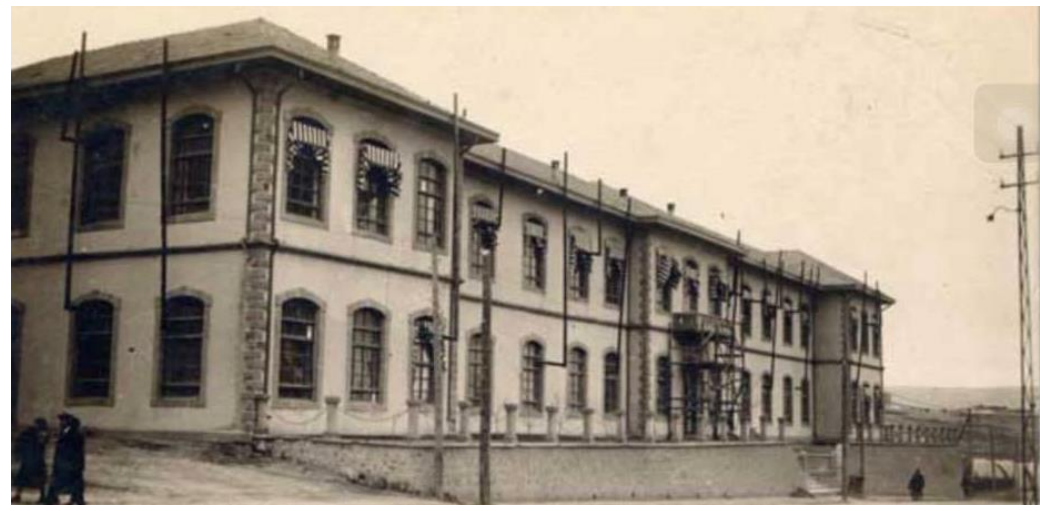

Resim 2: Ankara Sanayi Mektebi, yönetim-derslik yapısı, ön cephe (https://uluseml.meb.k12.tr)

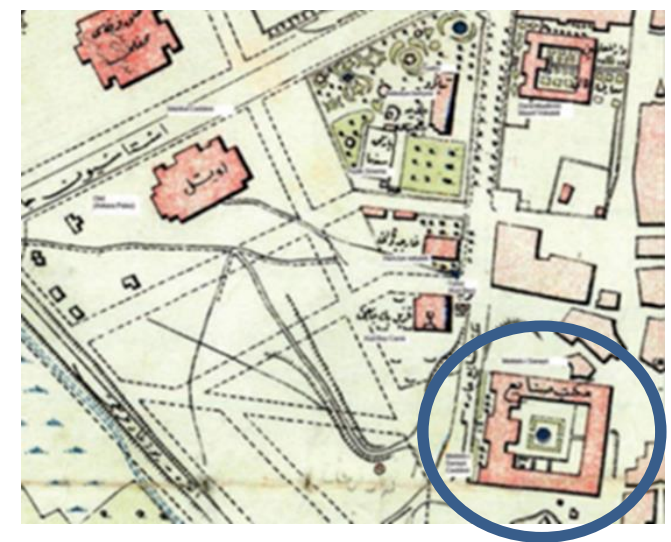

Şekil 3: 1924 tarihli Ankara Şehri Haritası'nda Ankara Sanayi Mektebi (Günel \& K1lc1, 2015, s.82)

Mimari bilinmeyen Ankara Sanayi Mektebi için Ulus semti merkezinde çevresinde Kızılbey Cami- Medrese-Türbesi ${ }^{4}(1299-1330)$, Darülmuallim ${ }^{5}$ (1901-1947), Taşhan ${ }^{6}$ (1888) ve Hariciye Vekaleti'nin yer aldığ boş bir alan seçilmiştir. Mektep parselinin üzerinde bulunduğu cadde, daha evvel Ankara Sanayi Mektebi'nden ismini alarak Mekteb-i Sanayi Caddesi olarak anılmıștır.

Kuruluşundan itibaren ilkokul düzeyinde, 1911 yllından itibaren ise ortaokul düzeyinde temel ve mesleki eğitimi birlikte veren Ankara Sanayi Mektebi, Cumhuriyetin ilanına kadar on bir farklı meslek dalıyla öğrencilerine eğitim imkanı sunmuştur. Mesleki eğitimin modernleşme sürecindeki değişimlerine kendi imkanlarınca ayak uydurabilmiş olan mektep; geleneksel ve el

\footnotetext{
${ }^{4}$ Kızılbey Cami, Alaadin Keykubad Dönemi emirlerinden Kızıl Bey tarafından yapılmıştır. 1299/1300 yıllarına tarihlendirilen caminin eski fotoğraflarından kerpiç duvarlı ve sivri çatılı bir yapı olduğu anlaşılmaktadır (Öney, 1971, s. 93). Caminin yanında inşa edilen Kızılbey Medresesi Ankara'nın en eski medreselerinden biridir ve XIII. yüzyılın başlarına tarihlendirilir. Kızılbey Türbesi hakkında bilgi bulunmamaktadır (Özdemir, 1986, s.51). Kızılbey cami, medrese ve türbesi Ulus Ziraat Bankası'nın inşaatı için yıkılmıştır.

${ }^{5}$ Darülmuallim'in tam olarak ne zaman açıldığı bilinmemekle birlikte mektebin adına ilk kez 1902 tarihli Ankara Vilayet Salnamesi'nde rastlanılmıştır. Ulus Meydanı'nda bugünkü Ulus İş Hanı'nın yerinde bulunan Darülmuallim, taş yığma yapım sistemi ile inşa edilmiş üç katlı bir eğitim yapısıdır. II. Abdülhamid Dönemi'nde inşa edilen yapı, Cumhuriyet Dönemi’nin başlarında mebuslar için yatakhane olarak kullanılmıştır. 1947 yılında çıkan bir yangınla harap olana kadar yapı bir müddet Maarif Vekaleti olarak kullanılmıştır. Yangından sonra mimari proje yarışması yapılmış ve yapının yerine bugünkü Emek Çarşısı ve İşhanı inşa edilmiştir (Erdoğan vd., 2008, s.77).

${ }^{6} 1888$ yılında inşa edilen Taşhan, ilk meclis kuruluncaya kadar bir Osmanlı şehir içi hanı olarak kullanılmıştır. 1928 yılında otele çevrilen yapının bir diğer adı da 'Hotel Angora'dır. Taşhan 1934-1936 yılları arasında Sümerbank binasının yapımı için yıkılmıştır (Erdoğan vd., 2008, s.41).
} 
işçiliğine dayalı mürettiplik, litografi, kaliçecilik, debbağlık, nisacelik, arabacılık meslek dallarını 1911 tertibatı ardından programından çıkartarak kunduracılık, marangozluk, demircilik ve tesviye alanları üzerinde yoğunlaşmıştır.

Ankara Sanayi Mektebi, Cumhuriyet'in ilanının ardından 1924 yılında sanat okuluna dönüştürülerek Osmanlı Dönemi'nde açılıp varlığını günümüze kadar sürdürebilen sanayi mektepleri arasında yer almayı başarabilmiştir. 1927 yılında Milli Eğitim Bakanlığı'na devredilen mektep $^{7}$ dönemin mesleki eğitim politikaları kapsamında; 1943 yılında sanat enstitüsüne, 1971 yılında meslek lisesine, 2000 yılında ise Anadolu meslek lisesine dönüştürülmüştür (Doğan vd., 2012). Bu süreçte mektep Osmanlı Dönemi'nden miras kalan marangozluk, demircilik ve tesviye meslek dallarını, ağaç işleri ve metal teknolojileri adı altında toplayarak bu mesleklerin devamlılığını sağlayabilmiştir. Ayrıca yine bu süreçte mektebin meslek dalları arasına elektrik, inşaat, kuyumculuk, galvanoplasti ve boyacılık eklenmiş olsa da elektrik dışındaki bu dallar mektep programında uzun ömürlü olamamıştır. Tüm bu değişimleri tarihi yapısında deneyimleyen Ankara Sanayi Mektebi, günümüzde Ulus Mesleki ve Teknik Anadolu Lisesi adı altında sanayiye katkıda bulunabilecek bireyler yetiştirmeye devam etmektedir.

\section{Ankara Sanayi Mektebi’nin Yerleşim Özellikleri}

Günümüzde Ankara Sanayi Mektebi, topoğrafik konumu ve kentsel doku içindeki ölçeği ile üzerinde bulunduğu caddeyi yatay hatla vurgulayan bir mesleki eğitim yapısıdır. Mektebin doğusunda Sanayi Caddesi, batısında Atatürk Bulvarı ve Ziraat Bankası (1926-1929), kuzeyinde Ulus PTT Binası (1982), güneyinde ise Kediseven Sokağı ve Yunus Emre Enstitüsü bulunmaktadır. Batıdaki ön avlulu ve merdivenli giriş cephesi ile Atatürk Bulvarı'na tarihi bir kesit sunan Ankara Sanayi Mektebi; kuzey-güney doğrultusunda uzanıp bulvara cephe veren yönetim-derslik yapısı ile arkasındaki iç avluyu doğu, kuzey ve güney yönlerden çevreleyen atölye yapılarından oluşmaktadır (Resim 4).

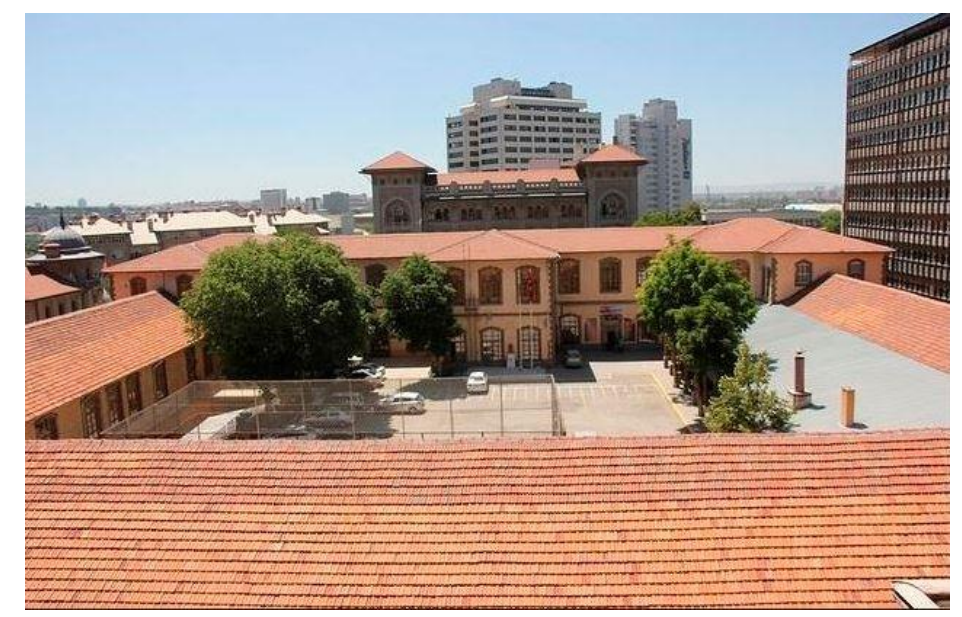

Resim 4: Ankara Sanayi Mektebi, iç avlu ve atölyeleri (https://uluseml.meb.k12.tr)

Bat1 ve doğu yönünde bulunduğu caddelerden bahçe duvarları ile ayrılan Ankara Sanayi Mektebi'nin üç girişi vardır. Mektebin ana girişi Atatürk Bulvarı üzerindeki ön cephenin orta aksında, arka girişi ise Sanayi Caddesi üzerinde ve simetri ekseninin kuzeydoğu köşesinde yer

\footnotetext{
${ }^{7}$ İnşa edildiği tarihten itibaren eğitim yapısı olarak kullanılan Ankara Sanayi Mektebi, Kurtuluș Savaşı sırasındaki savaș koşullarında yaşanan bina sıkıntısı nedeniyle, o dönemde Ankara'da mevcut olan yapıların devlet dairesi olarak kullanılması uygulamasına paralel olarak, 1930 yılına kadar Milli Müdafa Vekaletleri tarafından devlet dairesi olarak kullanılmıştır. $\mathrm{Bu}$ süreçte temel dersler kiralık olarak tutulan Eti Palas/Lozan Palas'ta verilirken, öğrenciler mektebin atölyelerinde ordunun giyim ve eşya ihtiyaçlarını karşılayan üretimler yaparak milli mücadeleye katkı sağlamıştır.
} 
almaktadır. Mektebin güneydoğu köşesinde ve ana giriş kodunun altında bulunan üçüncü girişi ise günümüzde kullanılmamaktadır.

Ankara Sanayi Mektebi’nin yönetim-derslik yapısı iki katlı olarak inşa edilmiştir. Yönetimderslik yapısını ve dikdörtgen planlı iç avluyu "U" biçiminde kavrayan atölyeler ise yönetimderslik yapısından alçak, birbirleri ile eş yükseklikte ve tek katlıdır. Günümüzde kuzey ve doğu atölye; metal teknolojileri, bilişim teknolojileri, ahşap teknolojileri, tesisat teknolojileri ve iklimlendirme meslek dalları için düzenlenmişken, güney atölye yapısı ise elektrik-elektronik ve metal teknolojileri meslek dalları için kullanılmaktadır. Arazideki kot farkı nedeniyle güney ve doğu atölye yapıları bodrum kat üzerine inşa edilmiş, bu atölyelerin bodrum katları arasında dolaşımın sağlanması amacıyla bir geçiş koridoru yapılmıştır (Resim 5).

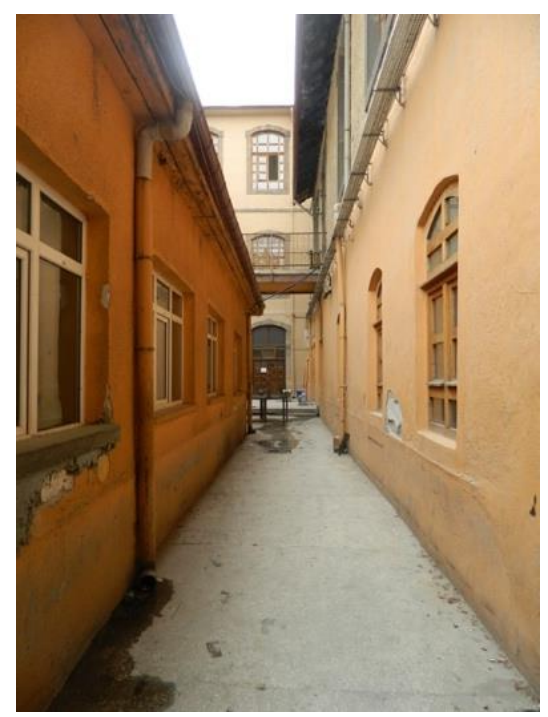

Resim 5: Ankara Sanayi Mektebi, geçiş koridoru (Çeber, 03.05.2017)

Dikdörtgen planlı iç avlu, hem öğrencilerin toplanma-dinlenme yeri hem de yönetimderslik yapısı ve atölyeler arasındaki dolaşımı sağlamaktadır. Genel anlamda zemini asfalt ile kaplı iç avluda; doğu atölye yapısının önünde basketbol sahası ile bu atölyenin bodrum katına inen merdiven kovası, kuzey atölye önünde revaklı bir giriş, doğu atölye yapısı ile basketbol sahası arasında kalan kısımda ise avludan doğu ve güney atölyelere geçit veren bir dolaşım koridoru yer almaktadir.

Bodrum kodundaki andezit taş kaplı geçiş koridoruna, iç avlunun güneybatı ucuna konumlandırılmış tek kollu merdivenden inilerek ulaşılır. Geçiş koridorunun yaklaşık orta aksına konumlandırılmış dikdörtgen planlı yemekhane, avlu istinat duvarına bitişik olacak şekilde inşa edilmiştir. Atölyelere ve yemekhaneye hizmet veren geçiş koridoru, mektebin üçüncü girişine açılan tonozlu bir geçite bağlanır. Günümüzde sadece güney atölye yapısı boyunca uzanan bu geçiş koridorunun, özgününde kuzey atölye yapısı ile doğu atölye yapısının birleştiği yere kadar devam edecek şekilde yapıldığı 1924 Ankara Şehri Haritası ile tarihsiz eski bir fotoğraftan tespit edilmiştir. Özgününde iç avluyu iki yönden kuşatan bu geçiş koridoru nedeniyle doğu atölye yapısına ulaşım adi/basit araba yolu ile sağlanmıştır. Ayrıca yine varlığını 1924 Ankara Şehri Haritası'ndan tespit edebildiğimiz iç avlunun ortasına konumlandırılmış daire planlı havuz, Cumhuriyet Dönemi'nde kaldırılmıştır.

Taş yığma yapım sistemi ile inşa edilen mektep, gerek plan gerekse cephe düzeni açısından simetrik olacak şekilde tasarlanmıştır. Mektep yapısına zaman içerisinde çelik strüktür ve betonarme ekler yapılmıştır. Marsilya kiremitin tercih edildiği mektebin yönetim-derslik yapısı basit kırma çatı ile atölye yapıları ise beşik çatıyla örtülmüştür. 


\section{Ankara Sanayi Mektebi’nin Tasarım Anlayışı ve Mimari Özellikleri}

Ankara Sanayi Mektebi'nin kuzey-güney doğrultusunda uzanan yönetim-derslik yapısı, dikdörtgen planlı ve iki katlı olarak inşa edilmiştir. Arazideki kot farkı nedeniyle yapının güney köşesi servis birimlerince kullanılan bodrum kat olarak değerlendirilmiştir. Yönetim-derslik yapısının zemin katına ön cephede ve simetri ekseninde yer alan ana giriş kapısından girilmektedir. Ana giriş kapısı önce rüzgarlık bölümüne ardından da giriş holüne açılmaktadır. Giriş holü, yapının her iki yanı boyunca uzanan ve karşılıklı olarak yerleştirilmiş farklı işlev ve büyüklükteki mekanlara ulaşımı sağlayan koridora uzanmaktadır. Kuzey-güney doğrultusu boyunca uzanan koridor, kütlenin her iki ucunda yer alan ve birinci kata ulaşımı sağlayan merdivenlerle sonlanır (Resim 6-7).
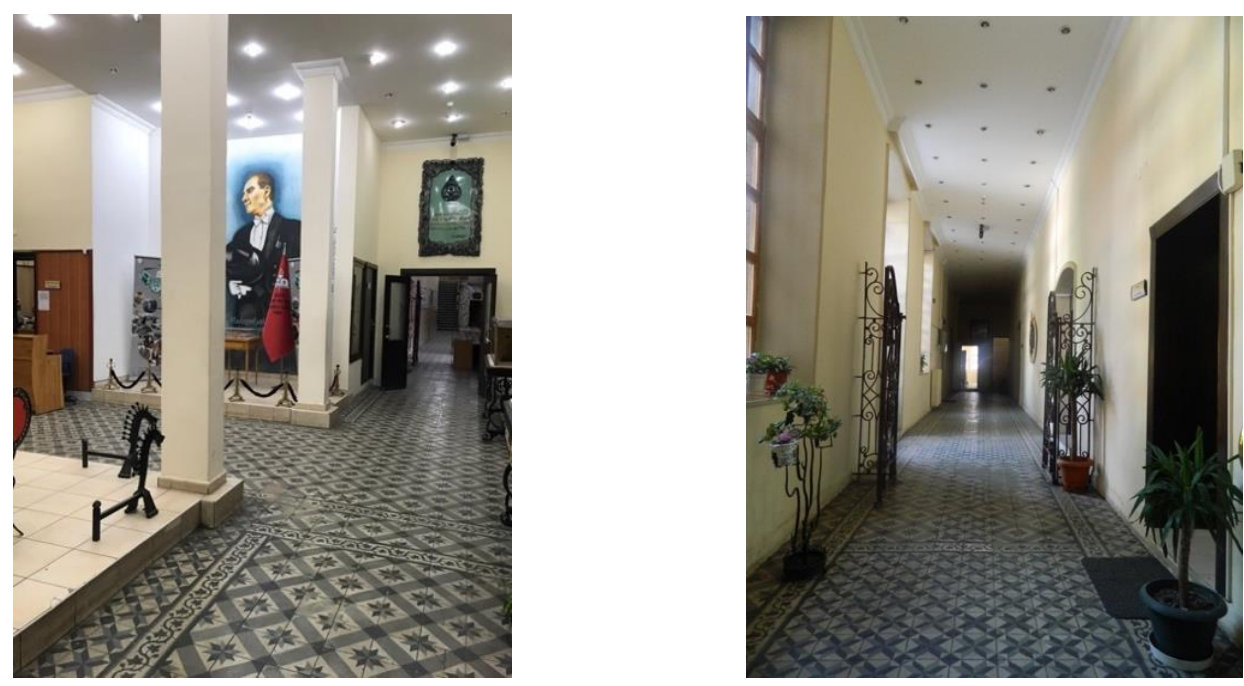

Resim 6-7: Ankara Sanayi Mektebi, yönetim-derslik yapısı, zemin kat, giriş hölü (sol); yönetimderslik yapısı, zemin kat, koridor (sağ) (Çeber, 03.05.2017)

Yönetim-derslik yapısının zemin ve birinci kat plan şemaları genel anlamda birbirini tekrar etmektedir. Osmanlı Dönemi'nde yapının zemin katı; sınıflar, yönetim birimleri ve servis mekanlarınca kullanılırken, birinci katı yatılı öğrenci ve öğretmen kadrosuna hizmet verecek şekilde düzenlenmiştir. Cumhuriyet Dönemi'nde mektebin yatılı kısmı kaldırılınca birinci katın mekansal düzeni çoğunluğu sınıf olacak şekilde tekrar düzenlenmiştir (Resim 8-9).
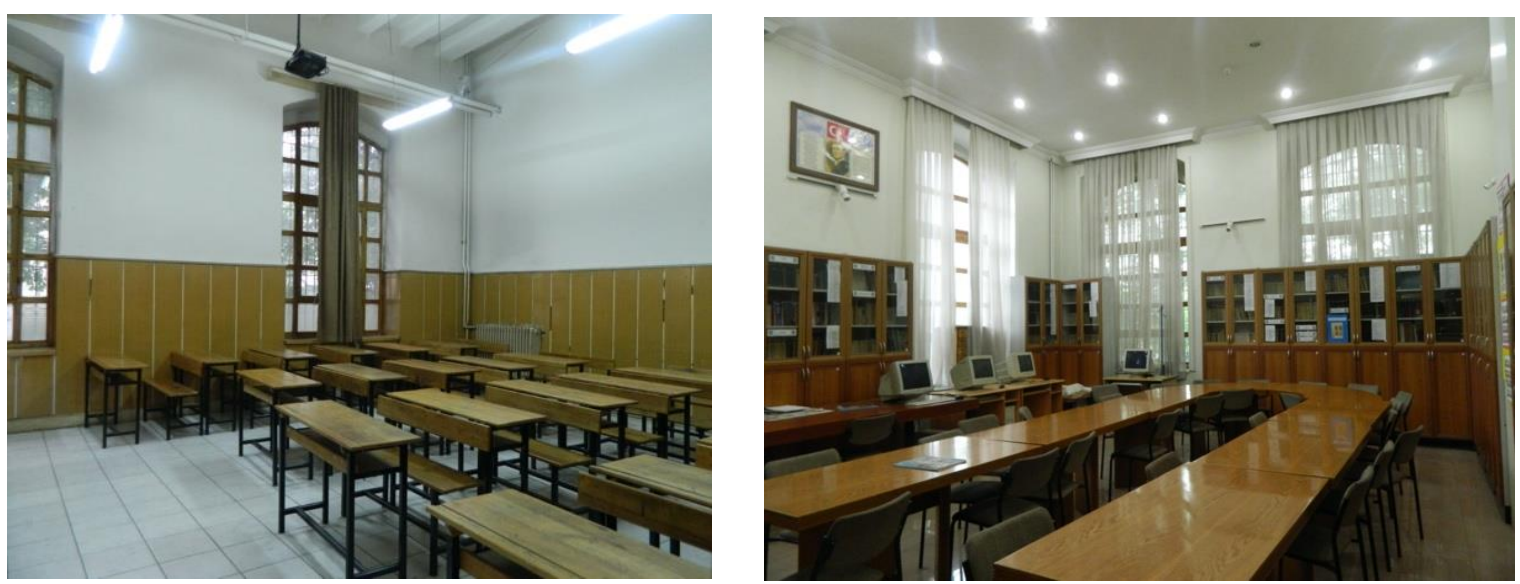

Resim 8-9: Ankara Sanayi Mektebi, yönetim-derslik yapısı, zemin kat, sınıf (sol); yönetimderslik yapısı, zemin kat, kütüphane (sağ) (Çeber, 03.05.2017) 
Ankara Sanayi Mektebi'nin iç avlusunu üç yönden çevreleyen atölye yapılarından kuzeydeki tek katlı, güney ve doğudaki ise bodrum üzerine iki katlı olarak inşa edilmiştir. Atölyeler özgününde bir ya da iki büyük çalışma alanı ile bu alanlara hizmet veren küçük mekanlardan meydana gelecek şekilde tasarlanmıştır. Atölyelerin bodrum ve zemin katları, tıpkı yönetim-derslik yapısı gibi, genel anlamda birbirini tekrar etmiştir. Geniş uygulama alanlarına sahip atölyelere Cumhuriyet Dönemi'nde birçok ek yapılmıştır. Bölme duvarlar ve asma katlar aracıllğı ile atölyelere çeşitli işlevlere sahip mekanlar eklenmiş bu yüzden atölyeler geniş çalışma alanlarını kaybetmiştir (Resim 10).

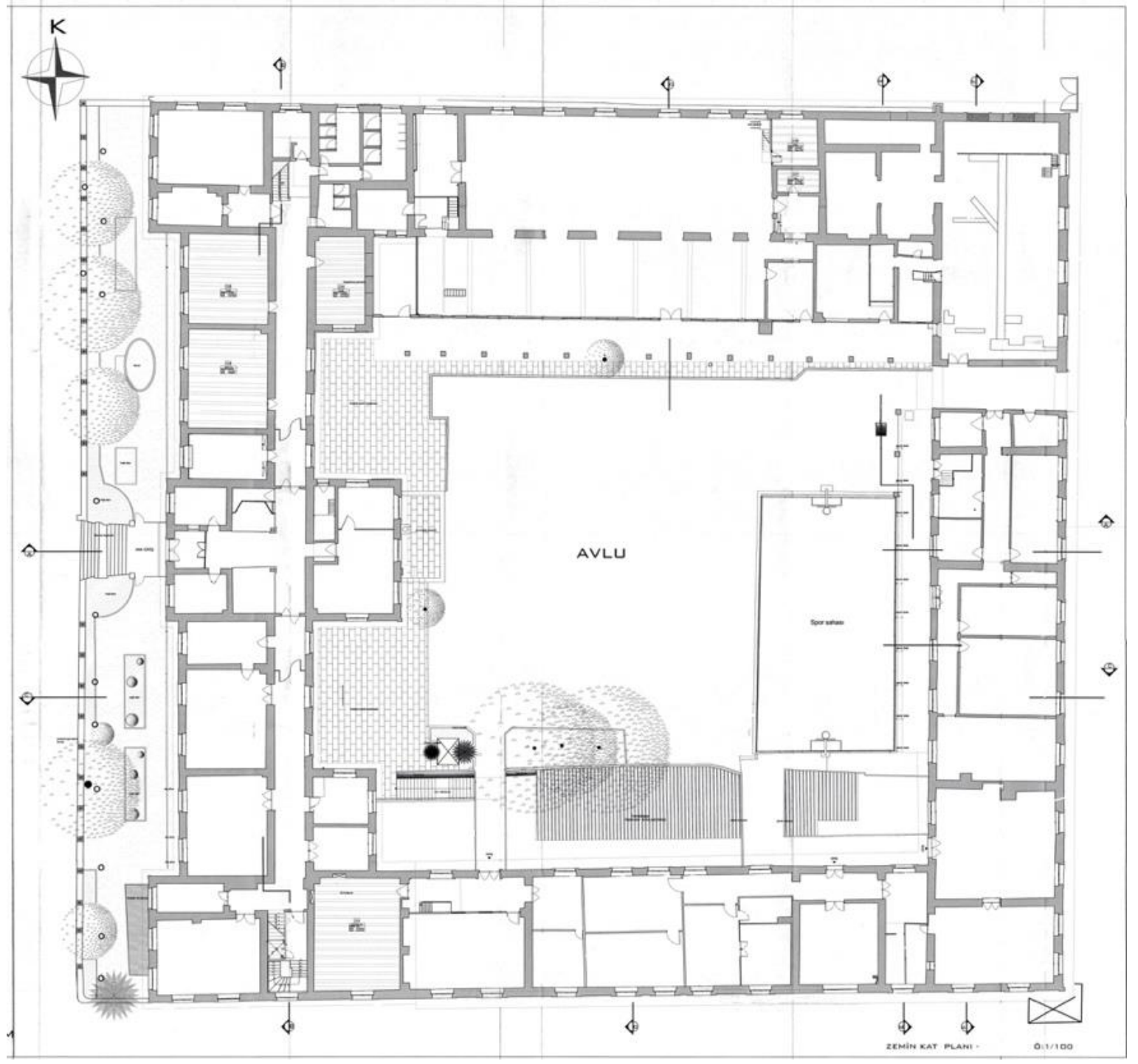

Resim 10: Ankara Sanayi Mektebi, zemin kat planı (Ankara Rölöve Anıtlar Müdürlügü, 2007)

Günümüzde kuzey atölye yapısı iki çalışma alanı ve bu alanlara hizmet veren servis mekanlarından oluşmaktadır. Güney ve doğu atölyenin zemin katı koridor boyunca konumlandırılmış mekanlardan meydana gelirken, bodrum katı ise kuzey atölye yapısının planı ile benzerlik göstermektedir. Güney atölye zemin kat koridoru ile doğu atölyenin bodrum katındaki B20 nolu mekanda kullanılan özgün karo mozaik yer döşemeleri, mimari süsleme açısından bu mekanları diğer atölye mekanlarından ayırmaktadır (Resim 11-12-13). 


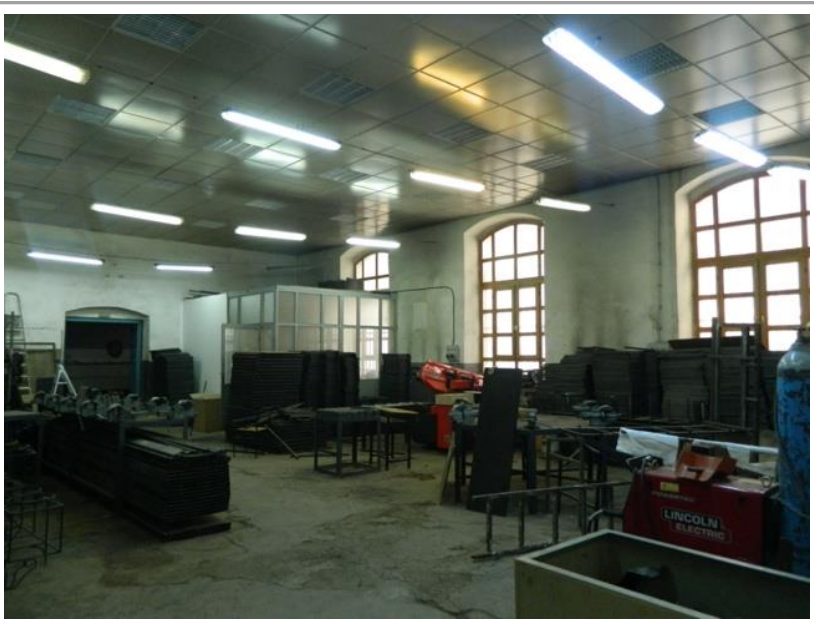

Resim 11: Ankara Sanayi Mektebi, kuzey atölye yapısı, metal teknolojileri alanı (Çeber, 03.05.2017)
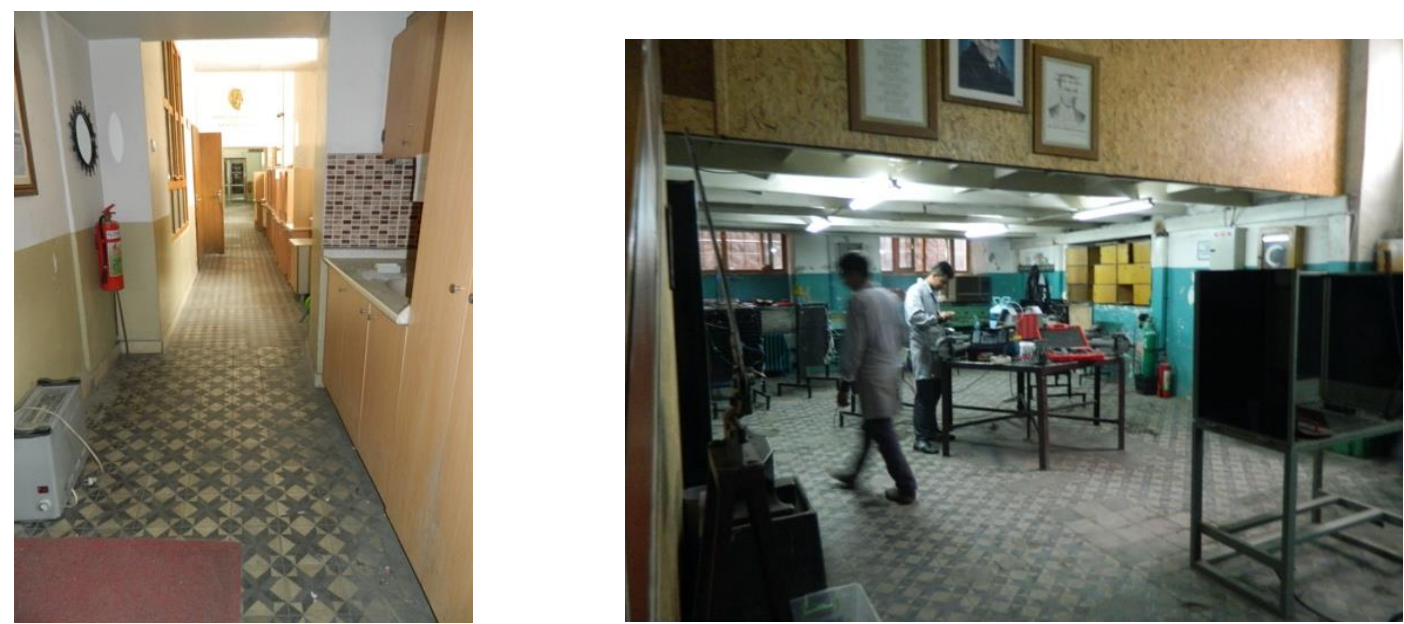

Resim 12-13: Ankara Sanayi Mektebi, güney atölye yapısı, zemin kat, elektrik-elektronik alanı (sağ); doğu atölye yapısı, bodrum kat, metal teknolojileri alanı (sağ)

(Çeber, 03.05.2017)

Mektebin sıva üzerine boyalı duvarlarında pencere hizasına kadar lambri şeklinde yağlı boya uygulanmıştır. Tavanları volta döşemeli mektebin onarım görmüş mekanlarına asma tavanlar eklenmiştir. Yönetim-derslik yapısında rüzgarlık, giriş hölü ve sınıf olarak kullanılan çoğu mekanda ahşap lambri tercih edilmiştir. Mektebin tüm kapıları kemer biçimleri (kemersiz/basık) ve kanat sayıları (1-2) bakımından dört gruba ayrılmaktadır. Mektebin ana giriş kapısı, dekoratif kapıları, iç avluya açılan kapıları, atölye yapılarının ana giriş kapıları demir malzemeden diğer bütün kapıları ise ahşap malzemeden yapılmıştır.

Yönetim-derslik yapısının zemin kat giriş holü ve koridoru, geometrik motiflerden oluşan iki farklı kompozisyon ve bu kompozisyonları çevreleyen bitkisel motifli bordürlerle kaplanmıştır. Yapının birinci katı ise, ıslak mekanlar hariç, dökme mozaik ile kaplıdır. Aralık 2016 tarihinde gerçekleştirilen restorasyon çalışmasında, dökme mozaik yer döşemeleri ve güney atölye yapısının zemin kat karo mozaik yer döşemeleri fayans ve laminat parke malzeme ile kapatılmıştır.

Ankara Sanayi Mektebi'nin yönetim-derslik yapısı ve atölyeleri simetrik cephe düzenlemesine sahiptir. Bulvar boyunca uzanan yönetim-derslik yapısının ön cephesi simetri 
ekseni ve köşelerindeki kütlelerin öne doğru çıkma yapmasıyla hareketlendirilmiştir. Öne çıkma yapan kütlelerin üçlü pencere düzeni her iki katta tekrar ederken, ana girişin yer aldığı kütle iki pencere ve bir kapı olacak şekilde düzenlenmiştir. Yönetim-derslik yapısının ana giriş kapısı, süsleme yoğunluğu ve konumu itibariyle ana girişi taçlandırmaktadır. Basık kemerli ana giriş kapısı dikdörtgen planlı ve iki kanatlıdır. Çeşitli geometrik ve bitkisel motifler ile süslenmiş demir doğramalı ana giriş kapısının iki yanında eş hizada duran iki metal fanus 1şıklık yer almaktadır. Ana giriş kapısı hizasında yer alan üst kat penceredeki mevcut izler, bu kısımda önceden bir balkon olduğunu işaret etmektedir" ${ }^{8}$ Çıkma yapan kütlelerinin gerisinde kalan kısımlar ise her iki katta ritmik tekrar eden beşli pencere düzenine sahiptir. Yönetim-derslik yapısının iç avlu cephesinde, köşelerdeki çıkmalara bitişik iki kütle daha yer almaktadır. İkili pencere düzenine sahip bu kütlelerin haricindeki diğer çıkmalarda ise üçlü pencere düzeni tercih edilmiştir. Ayrıca bu cephe su basman seviyesine kadar rustika ile kaplanmıştır. Yapının çıkmasız kuzey ve güney yan cephelerindeki hareketlilik ise köşe taşları, silmeler ve birbirini tekrar eden pencere sıraları ile verilmiştir (Resim 14).

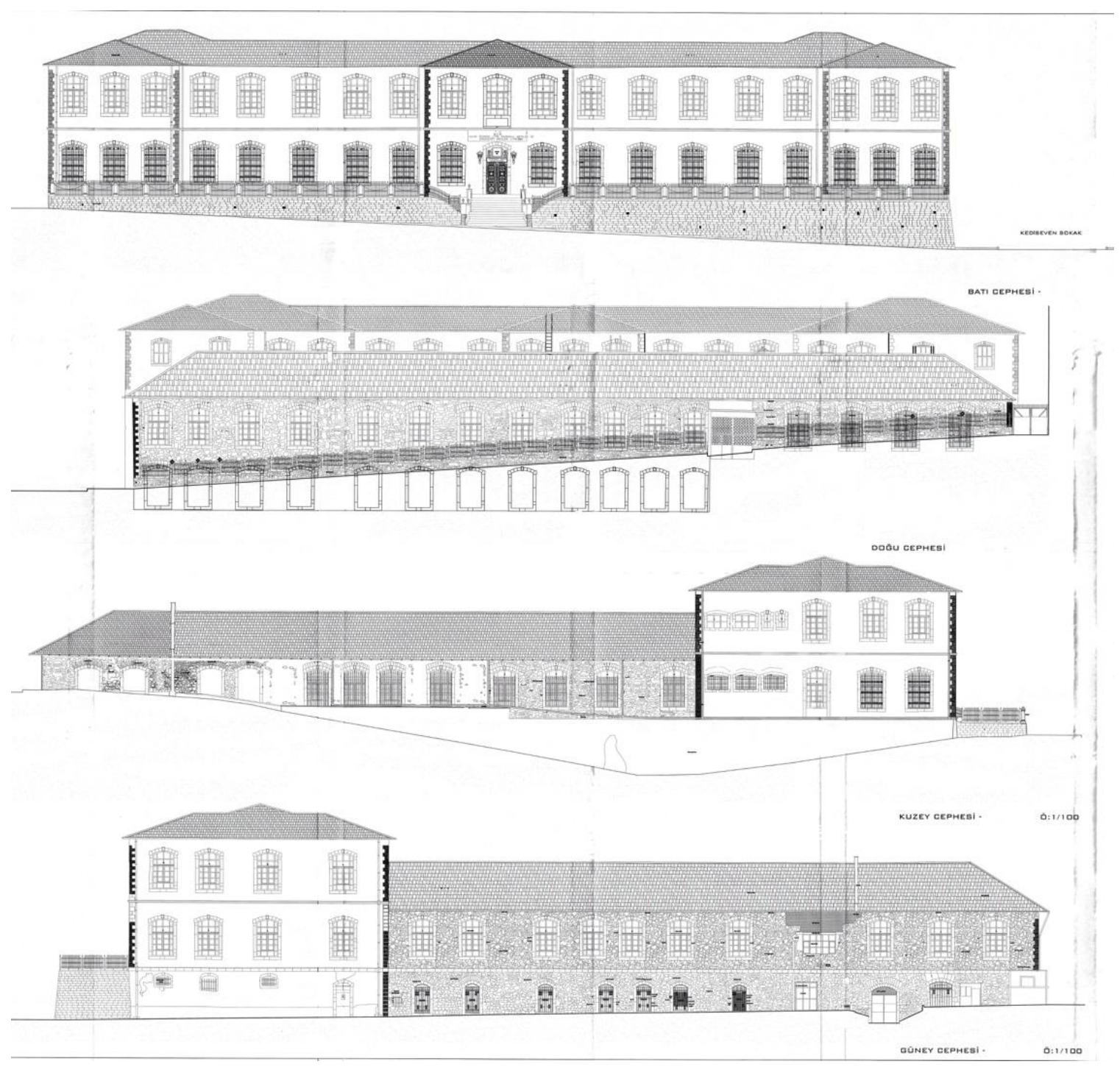

Resim 14: Ankara Sanayi Mektebi, cephe görünüşleri (Ankara Rölöve Anıtlar Müdürlüğ̈̈, 2007)

\footnotetext{
${ }^{8}$ Dikdörtgen planlı balkon Cumhuriyet Dönemi’nde 1933 yılından önceki bir tarite kaldırılmıştır.
} 
Ankara Sanayi Mektebi'nin atölye yapıları, yönetim-derslik yapısının ön ve arka cephelerindeki hareketliliğine karşıt oluşturacak şekilde boylu boyunca uzanan taş kaplı sıvasız düz cephelere sahiptir. Atölyelerin taş kaplı cephelerinde teknik uygulamanın farklılaştı̆̆ görülmektedir. Kuzey atölye ile güney atölyenin bodrum kat cephesi taş örgü duvar iken, doğu atölye ile güney atölyenin zemin kat cephesi kaynak taş kaplıdır. Atölyelerin köşeleri çıkıntılı/rustik örgülerle kaplanmışken, kat silmeleri yapı boyunca devam eder. Basık kemerli ve taş söveli pencelerine ayrıca kaynak taşı basık kemer eklenmiştir.

Cadde/sokak cephelerinden atölyelere bakıldığı zaman; arazideki kot farkı nedeniyle güney atölyenin bodrum katının tamamı, doğu atölye yapısının bodrum katı ise kısmen görülmektedir. Kuzey atölye yapısının açıklıkları cepheye ritmik olmayacak şekilde yerleştirilmişken, güney ve doğu atölye yapısının her iki katındaki açıklıklar ise neredeyse aynı hizaya gelecek şekilde konumlandırılmıştır. Güney atölyenin zemin kat hizasındaki sekizinci pencere açıklığı yıkılmış, y1kılan kısım tuğla malzemele ile tamamlanarak buraya özgününe uymayan dikdörtgen planlı bir pencere eklenmiştir. (Resim 15-16).
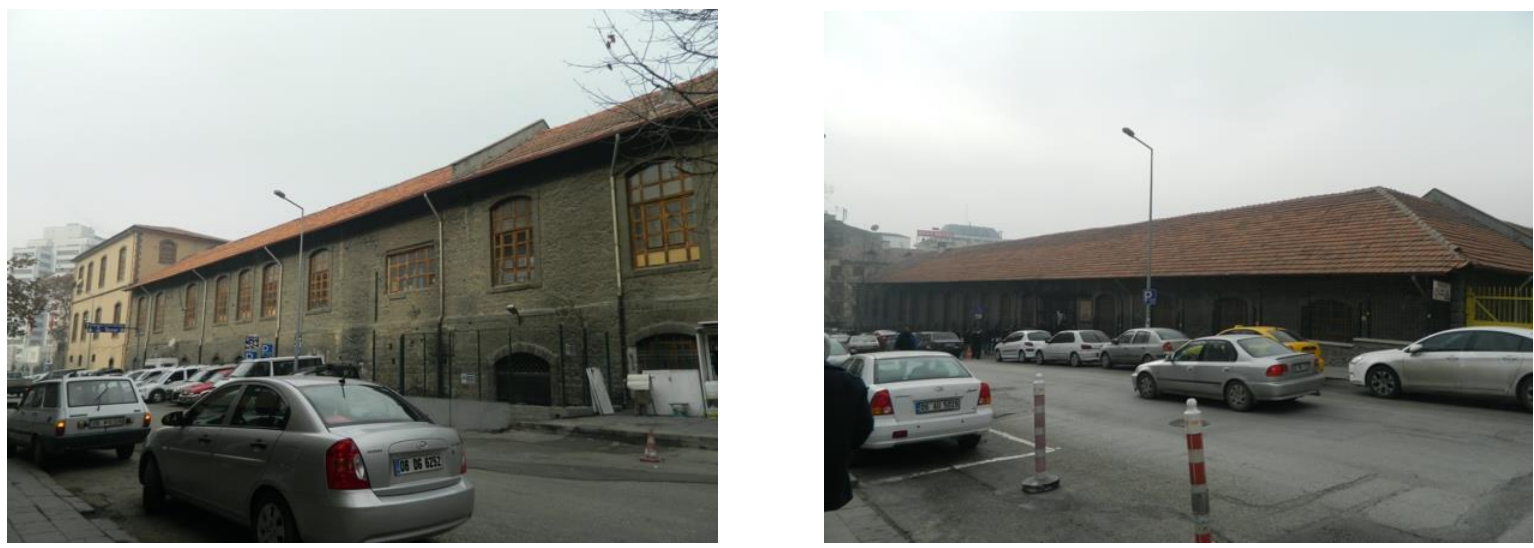

Resim 15-16: Ankara Sanayi Mektebi, güney atölye yapısı (sol); Doğu Atölye Yapısı (sağ)

(Çeber, 03.05.2017)

İç avludan atölyelere bakıldığında kot farkı nedeniyle atölyelerin sadece zemin katları görülmektedir. Doğu atölye cephesinin aksine açıklıkla güney ve kuzey atölye cephesine ritmik olmayan düzende yerleştirilmiştir. Güney atölyenin iç avluya bakan cephesi, atölyeye uzanan iki köprü ve metal korkuluklarla avludan ayrılmaktadır (Resim 17).

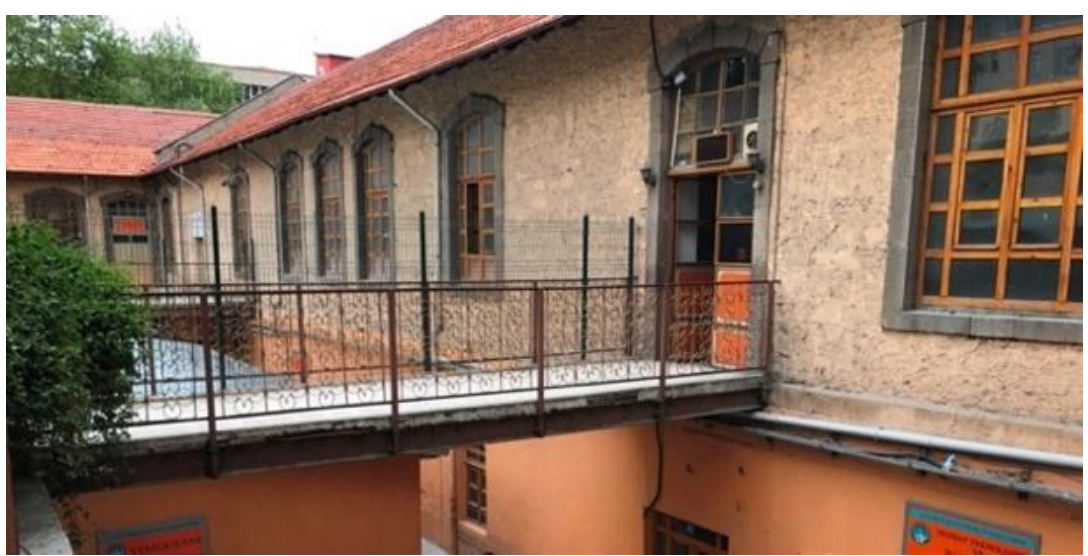

Resim 17: Ankara Sanayi Mektebi, güney atölye yapısı, iç avlu cephesi (sağ) (Çeber, 03.05.2017) 
Kuzey atölye yapısının iç avlu cephesi ise, özgün atölye yapısına eklenen kütle nedeniyle diğer atölye cephelerinden farklılaşmıştır. Subasman seviyesine kadar rustika ile kaplı atölye cephesine, özgün açıklıklardan farklı olarak, dikdörtgen planlı ve kemersiz açıklıklar yapılmıştır. Sıva üzerine boyalı atölye cephesinin önüne ayrıca taş kaplama kaidelerin taşıdığı bir revak eklenmiştir (Resim 18).

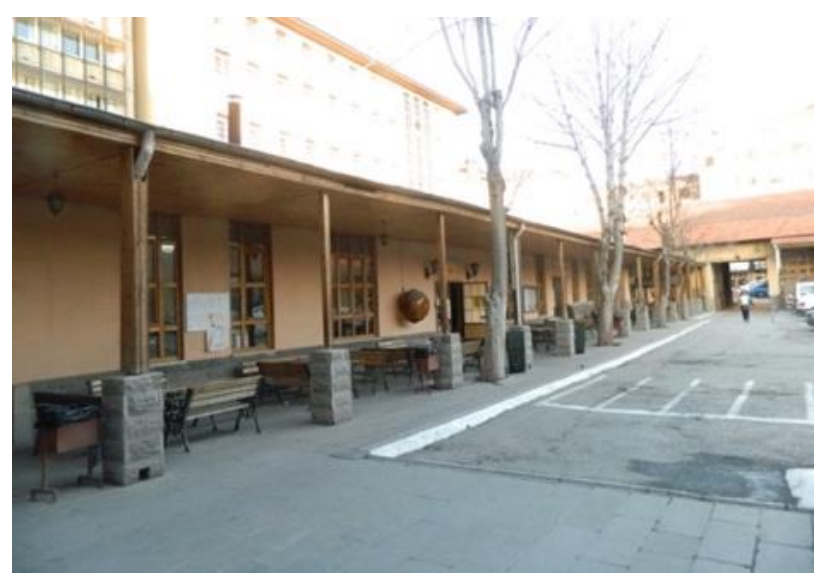

Resim 18: Ankara Sanayi Mektebi, kuzey atölye aapısı, iç avlu cephesi (Çeber, 03.05.2017)

Yalın bir cephe anlayışına sahip olan Ankara Sanayi Mektebi'nin cepheleri, mimari süsleme elemanları ile hareketlilik kazanmıştır. Yapının katları birbirinden yatay taş silmeler ile ayrılmışken, tüm köşeleri köşe taşları ile kaplanmıştır. Köşe dizilerinde gri andezit taş kullanılmıştır ve bu taşlar köşelere boyutları bakımından atlamalı olarak yerleştirilmiştir. Köşe taşları, pürüzlü dış yüzeyleri ve vurgulanmış derzleriyle yapının cephelerine doğal bir doku katmaktadır. Aynı doku hissi, yönetim-derslik ve kuzey atölye yapısında kullanılan rustikalar ile verilmiştir. Mektebin özgün kapı ve pencere açıklıkları dikdörtgen planlı ve basık kemerlidir. Taş söveler ile çevrelenmiş açıklıkların kilit taşları vurgulanmış ve kemer kuşağındaki taşlar atlamalı olarak yükseltilmiştir.

Uzun bir tarihi geçmişe sahip olan ve 1933 yılında "Kagir Sanayi Binası" adı ile tescil edilen Ankara Sanayi Mektebi'nin özellikle atölye yapılarında birçok kez onarım ve yenileme çalışmaları yapılmış olsa da mektep büyük ölçüde özgün mimari plan ve cephe özelliklerini koruyarak günümüze kadar gelebilmiştir.

\section{Değerlendirme ve Sonuç}

Osmanlı modernleşmesinin sanayi ve eğitim alanındaki etkileri, zaman içerisinde sanayi mekteplerinin şekillenip gelişmesini ve bu mekteplerin eğitimine uygun yapıların ortaya çıkmasını sağlamıştır. Geç Osmanlı Dönemi'nin yeni yapı türleri arasında yerini alan sanayi mektepleri, modernleşen meslek eğitiminin mimariyi nasıl şekillendirdiğini örneklemesi açısından önemlidir. Sanayi mektebi öğrencilerinin mesleki becerilerini geliştirebilmeleri için atölye çalışmalarına ihtiyaç duymaları ve bu ihtiyaç doğrultusunda yönetim-derslik yapısından ayrı bir yapı olarak atölyelerin inşa edilmesi, mimari açıdan bu mektepleri diğer eğitim yapılarından farklılaştırmıştır. Yapıların arsa içerisinde konumlandırılmaları, servis birimlerinin çalışma mekanlarıyla olan bağlantıları, mekanların büyük açıklıklar aracılığıyla olabildiğince gün 1şığı ve hava almaları sanayi mekteplerinin tasarım anlayışına etki eden önemli faktörlerdendir.

Sanayi mekteplerinin değerlendirilmesinde önemli bir örnek olarak karşımıza çıkan Ankara Sanayi Mektebi, Osmanlı modernleşmesinin hem mesleki eğitimdeki hem de mimari ölçekteki bir 
yansımasını bizlere sunmaktadır. Eğitim hayatına 1slahhane olarak başlayan mektebin devlet düzenlemesinden önce 1876 yılında sanayi mektebine dönüştürülmesi dikkat çekicidir. $\mathrm{Bu}$ bağlamda belki de Ankara Sanayi Mektebi, 1slahhaneden sanayi mektebine dönüştürülen ilk mektep olma özelliğini taşımaktadır. Hem Osmanlı hem de Cumhuriyet Dönemi'ne tanıklık edebilen mektep sürekli müfredat ve isim değişikliği yaşamış olsa da kuruluş gayesinde benimsenen meslek eğitimine her zaman programında yer verebilmiştir.

Ankara Sanayi Mektebi, 149 yıllık eğitim ve yaşam birikimini temelleri 1901 yılında atılan ve 1924 yılından önceki bir tarihte tamamlanan tarihi yapısında deneyimlemiştir. Bankalar Caddesi'nin kimliğinin oluşmasına katkı sağlayan ve onu tanımlayan yapılardan biri olan Ankara Sanayi Mektebi’nin üzerinde yer aldığı caddeye isminin verildiğini görmekteyiz. Tamur (2010, s.64) "1924 haritasında yer alan Mektep-i Sanayi Caddesi gibi Ankara'nın ilk cadde isimlerinin resmi isimlerden ziyade, 1924 haritasını hazırlayanlar tarafindan verilen pratik tanımlamalar olduklarını" belirtmektedir. Değişim sürecindeki Ankara'nın ilk caddelerinden birine mektebin isminin verilmesinin altında yatan sebebin, pratik tanımlanın ötesinde anlam taşıdığı yadsınamaz bir gerçektir. Çünkü Ankara Sanayi Mektebi, sahip olduğu çok yönlü özellikleriyle Ankara kenti için övünç kaynağı olarak sayılmıştır. Mektep hem Ankara'nın sanayi tarihinin bir parçası olabilmiş hem de mimari yapısıyla değişim sürecindeki kentin görsel sahnesine değişmez ve önemli katkılarda bulunabilmiştir. Ankara'nın başkent oluşuna ve yoğunlaşan imar faaliyetlerine de tanıklık eden mektepten mezun olanlar; meslek okullarında öğretmenlik yapmış, kendi açtıkları atölyeler ve dükkanlarda yerel üretime destek vermiş, Ankara ve çevre illerde faaliyette olan sanayi kuruluşlarında görev alabilmiştir.

Ankara Sanayi Mektebi, Ulus'un merkezinde Osmanlı'dan Cumhuriyet'e aynı işlevi sürdürebilmiş tek eğitim yapısıdır. Bankalar Caddesi'ne tarihi bir kesit sunan söz konusu eserin sahip olduğu iç avlulu plan şeması, yeni bir uygulama olmayıp ana hatlarıyla Selçuklu medreselerinden başlayıp Osmanlı hanları ile devam ederek yüzyılın son çeyreğinde özellikle de kışla ve çeşitli eğitim yapılarında tercih edilen bir şemadır. Mektep iç avlulu plan şeması ile farklı alanlarda eğitim hizmeti vermiş Kuleli Kışlası (1827-1828), Taşkışla (1846-1852), Gümüşsuyu Kışlası (1860), Darülfünun (1854), Darülmuallim (1901) Haydarpaşa Mekteb-i Tıbbıye-i Şahane (1894-1903) ile paralel özelliklere sahiptir. İzmir Sanayi Mektebi, İstanbul Sanayi Mektebi, Bursa Sanayi Mektebi, Diyarbakır Sanayi Mektebi, Konya Sanayi Mektebi ve Kastamonu Sanayi Mektebi ise yönetim-derslik yapısının yanına ya da arkasına bağımsız olarak konumlandırılan atölye yapılarıyla Ankara Sanayi Mektebi'nden farklı tasarlanmıştır (Resim 19-20).
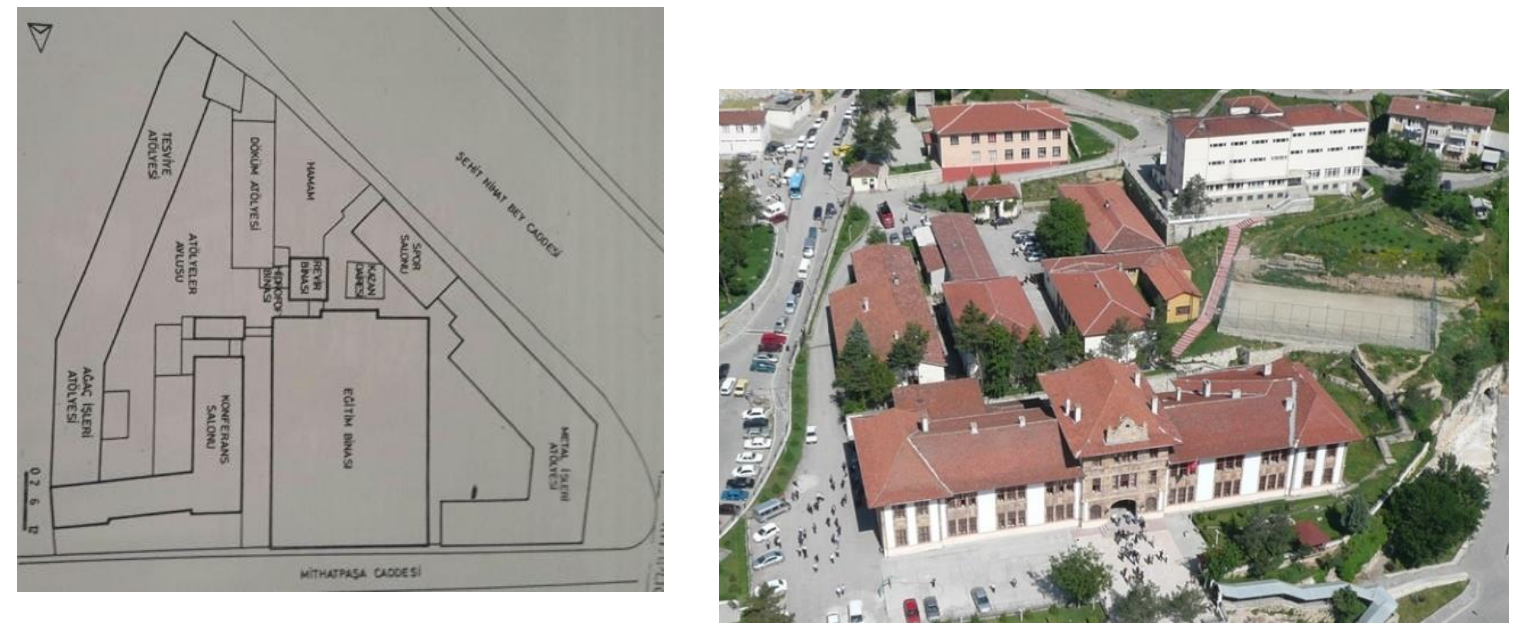

Resim 19-20: İzmir Sanayi Mektebi vaziyet planı (sol), Kastamonu Sanayi Mektebi (sağ) (İpekoğlu \& Hamamcioğlu, 2002, s.9) 
Öğrencilerine hem eğitim hem de barınma olanaklarını tek çatı altında sunabilmiş Ankara Sanayi Mektebi, tasarımı ve mekan kurgusuyla döneminin mesleki eğitim modelini yansıtmaktadır. Plan şeması bağlamında yönetim-derslik yapısı ile döneminin eğitim yapıları arasında belirgin bir fark bulunmamaktadır. Yönetim-derslik yapısı teorik derslere, idari birimlere ve yatılı öğrenci/öğretmenlere hizmet verdiği için bu yapıda uygulama alanlarına yer verilmemiştir. Yönetim-derslik yapısının özgün mekânsal düzeni Cumhuriyet Dönemi'nde mektebin yatılı kısmı kaldırılınca ve öğrenci sayısı artınca değişikliğe uğramış, bu yüzden yapının birinci katı çoğunluğu sınıf olacak şekilde tekrar düzenlenmiştir.

Ankara Sanayi Mektebi'nin ayrı yapılar olarak inşa edilen yönetim-derslik yapısı ile atölyelerinin ilişkisi iç avlulu plan şeması sayesinde kopmamıştır. Farklı meslek dallarında uygulama yapan öğrencilerin bir arada bulunmaları dikkatlerini dağıtıp, malzeme ve alet bakımından da karışıklığa sebep olacağı için, her meslek dalının atölye yapısının ayrı olarak inşa edilmesi tercih edilmiştir. Bu sayede her atölye kendi servis birimleri ve kadrosuyla kendine yetebilme özelliğine de sahip olabilmiştir. Zamanla değişen koşullar ve ihtiyaçlar doğrultusunda mektebin en fazla müdahale geçiren kısımları özgününde büyük çalışma alanlarına sahip olan atölyelerdir. Cumhuriyet Dönemi'nde atölye mekanlarında meydana gelen değişimlerin, öğrenci ve meslek dallarındaki artışın yanı sıra bu dönemde meslek okulları için hazırlanan planlardaki mekânsal belirlemeler doğrultusunda gerçekleştirilmiş oldukları düşünülebilir9 .

Geç Osmanlı Dönemi'nin genel karakteri içerisinde değerlendirilen Ankara Sanayi Mektebi'nin cephelerinde, Avrupa mimarisine damga vuran Paris Güzel Sanatlar Okulu ${ }^{10}$ nun (Ecolé des Beaux-Arts) mimari tasarım ilkelerine ait yansımalar görülür. Beaux-arts mimari tasarım ilkelerinde bir yapı planı, işlevi ve cepheleri ile uyum içinde tasarlanır. Eksene dayalı simetrik planlı yapıların simetri eksenleri, özellikle de giriş ekseni, kütlesel olarak öne taşırılarak vurgulanır (Akpolat, 1991, s.32). Girlandlar, madalyonlar, silmeler, rustik taş bloklar, köşe taşları, pılastırlar ve sütunlar cephelerde kullanılan başlıca mimari süsleme elemanlarıdır (Kılıç, 2006, s.23).

Ankara Sanayi Mektebi planı, işlevi ve cepheleriyle bütüncül bir anlayışla ele alınmıştır. Cephelerinin beş parçaya bölünerek simetri eksenlerinin ve köşelerinin öne taşırılarak vurgulanması mektebin beuax-arts ilkelerine uygun olarak tasarlandığını göstermektedir. Yalın cephelerinde sadece kat silmesi, köşe taşları ve rustika kullanılan mektep, mimari süsleme bağlamında ise Avrupa'daki kamu yapılarına kıyasla çok daha sade bir tutumla ele alınmıştır. Tüm bu bilgiler 1şı̆̆ında mimari özellikleriyle Ankara Sanayi Mektebi’nin sadeleştirilmiş neo-Rönesans üslup özelliklerini bünyesinde barındırdığını söylemek yanlış olmayacaktır. Ayrıca Geç Osmanlı Dönemi’nde (19. yüzyılın son çeyreğinden 1908 yılına kadar) inşa edilen yeni işlevli kamu yapıları, özellikle gar ve eğitim yapılar1 ${ }^{11}$, Ankara Sanayi Mektebi ile benzer mimari cephe

\footnotetext{
${ }^{9}$ Cumhuriyet Dönemi’nde Teknik Öğretim Müsteşarlığı'nda kurulan Yapı İşleri Müdürlüğü, sanat okullarının özellik ve ihtiyaçlarına göre inşa edilecek yeni okul yapılarının projelerini hazırlamıştır. P. Bonatz, Yapı İşleri Müdürlüğü’nün proje bürosu müşavir mimarı olarak 1943-46 yılları arasında burada görev yapmıştır. Hazırlanan projeler için bkz. Oran, S. (1952). Erkek orta sanat okullarl ve erkek sanat enstitüleri [Yayımlanmamış yeterlilik tezi]. İstanbul Teknik Üniversitesi Fen Bilimleri Enstitüsü.

101968 yılında kapatılıncaya kadar Güzel Sanatlar Okulu, Alplerin kuzeyindeki en eski sanat ve mimarlık okulu olmuştur. Bu prestijli kurumun kökenleri Kraliyet Mimarlık Akademisi'ne (Academie Royale d'Architecture) dayanmaktadır. Okulun mimarlık anlayışı döneminin sanatında etkin olmuş ve bu anlayış beaux-arts mimari tasarım ilkeleri olarak adlandırılmıştır. Beaux-arts'ın mimari tasarım ilkeleri Fransa başta olmak üzere İngiltere, Amerika ve diğer Avrupa ülkelerinde etkili olmuştur. Dresden Opera House ve Saint-Geneviene Kütüphanesi, bu ilkelere göre tasarlanmış Avrupa'daki önemli örnekler arasında yer alır (Draper, 1976, s. 209).

${ }^{11}$ Dönemin gar yapıları yabancı şirketlere (Fransız, İngiliz ve Alman) verilen imtiyazlar ile yapıldıkları için, kendileri ile aynı dönemde inşa edilen Avrupa'daki gar yapıları ile benzer mimari plan ve cephe özelliklere sahiptir (Demiraslan, 2014, s.1640). Aynı şekilde bu dönemde inşa edilen eğitim yapıları incelendiğinde Osmanlı Devleti'nin sadece Fransız
} 
özelliklerine sahiptir. Osmanlı modernleşmesinin ekseninde Fransa'nın yer alması, Güzel Sanat Okulu'nun eğitim ve mimari ilkeleriyle o dönemde etkili olması bu bağlamda da Sanayi Nefise Mektebi'nin beaux-arts ekolünü örnek alarak kurulması beaux-arts mimari tasarım ilkelerinin seçimindeki etkenler arasında sayılabilir.

Sade cephelerinin mimari ögelerle hareketlendirildiği Ankara Sanayi Mektebi'nin iç mekanlarında da aynı sadelik tutumu devam ettirilmiştir. Bu dönemde başta İstanbul ve İzmir olarak üzere apartman, okul, hastane, han ve otel gibi farklı işlevlere sahip yapılarda mimari süsleme elemanı olarak karo mozaik yer döşemeleri sıklıkla kullanılmıştır. Ankara Sanayi Mektebi'nin yönetim-derslik yapısının zemin kat koridoru ile güney ve doğu atölyelerin bazı mekanlarının dönemin bu yaygın süsleme anlayışına uygun olarak döşendiği görülmektedir. İzmir Sanayi Mektebi, Edirne Rüştiye Mektebi, Konya Darülmuallimin, İstanbul St. Benoit Fransız Erkek Okulu, Giustınıanı İtalyan Okulu, Merkez Rum Kız Okulu ve Anarat Higutyun Ermeni Katolik Okulu Ankara Sanayi Mektebi ile aynı karo mozaik döşemelere sahip olan eğitim yapılarındandır. Ankara Sanayi Mektebi'nin mimari süsleme açısından dikkat çeken diğer elemanları; ana giriş kapısı, zemin kattaki dekoratif kapıları, bahçe korkulukları ve ana girişteki aydınlatma elemanlarıdır. Cumhuriyet Dönemi'nde mektep öğrencilerinin atölye çalışmaları kapsamında yaptıkları bu temrinlerin mimari süslemede kullanılması, mektebin öğrencilerine ve onların temrinlerine verdiği değeri göstermesi açısından ayrıca önem taşımaktadır.

Ankara Sanayi Mektebi'nin önemli sorunsallardan biri mimarının kimliğinin bilinmemesidir. Döneminin mimari anlayışını yansıtan mektebin mimarının kimliği hakkında şu ana kadar hiçbir belge ve kayıta rastlanılmasa da dönem örneklerinden yola çıkarak bu konuda çıkarımlarda bulunabilmek mümkündür. Öncelikle Sanayi Nefise Mektebi'nin kuruluşu ardından inşa edilen Ankara Sanayi Mektebi’nin mimarının Sanayi Nefise'de eğitim almış bir mimar olabileceği düşünülebilir. Aynı cadde üzerinde konumlandırılan Ankara Sanayi Mektebi ile Darülmuallim'in iç avlulu plan şemasına ve benzer cephe özelliklerine sahip oldukları görülmektedir. Bu bağlamda bu yapılar, aynı mimar ya da aynı eğitimi almış mimarlar tarafından tasarlanmış olabilir. Ayrıca sanayi mektepleri arasında yer alan Konya Sanayi Mektebi'nin vilayet başmühendisi Şefik Bey tarafindan inşa edilmesi Ankara Sanayi Mektebi'nin de Ankara vilayet başmühendisi tarafından tasarlanmış olabileceğini düşündürmektedir.

Ankara Sanayi Mektebi'nin mevcut diğer sorunsalı ise mektebin yapım sürecindeki belirsizlik ve uzunluktur. Mektebin ana duvarlarının, açıklıklarının ve iç avluyu U biçiminde çevreleyen atölyelerin şekillendiği plan şemasının 1911 tertibat planı ile büyük ölçüde örtüşmesi onu hem Geç Osmanlı Dönemi mimarisi içinde hem de sanayi mektepleri arasında ayrıcalıklı bir konuma getirmiştir. Mektebin yapım sürecindeki belirsizlik nedeniyle hangisinin öncül olduğu sorusunun cevabı tam netlik kazanamasa da tarih akışı ve mevcut bilgiler ışı̆̆ında oluşan iki olasılık üzerinden bu soruya cevap aranabilir. Birinci olasılık, inşaat süreci 1901 yılında başlayan Ankara Sanayi Mektebi için hazırlanan tüm planın beğenilip, Ticaret ve Nafia Nezareti tarafından 1911 teritbat planına aktarılmış olması üzerinedir. Planlar arasındaki örtüşmenin neredeyse birebir olması bu olasılığı güçlendiren niteliktedir. İkinci olasılık ise mektebin bir kısmı ile tertibat planına örnek olması üzerine kuruludur çünkü 1911 tertibat planı yayınlandığında Ankara Sanayi Mektebi'nin inşaatı 1909 yılında durdurulmuştur. İnşaatının hangi aşamada durdurulduğu bilinmeyen mektebin yeni yapısına taşınma tarihi, mektebin en popüler olduğu 1907 yılı ise olasılıkla bu tarihte mektebin yönetim-derslik yapısının tamamı atölyelerinin ise ancak bir kısmı bitirilmiştir. Bu durumda Ankara Sanayi Mektebi mevcut haliyle 1911 planına öncü olmuş, 1915 yılında inşaatı devam eden atölyeler ise 1911 planını örnek alarak tamamlanmış olabilir. Tarih akışı içerisinde yorumlanan her iki olasılıkta görülüyor ki; tamamı ya da bir kısmı ile Ankara Sanayi

eğitim sistemini değil aynı zamanda bu sistem içinde tasarlanan eğitim yapılarının mimari plan ve cephe özelliklerini de örnek alıp uyguladığ anlaşılmaktadır (Kutlu, 2018, s.20). 
Mektebi tasarım anlayışı ve mimari özellikleriyle o zamana kadar inşa edilmiş sanayi mektepleri arasından en uygunu olarak seçilmiş, böylece yeni inşa edilecek/elden geçirilecek olan sanayi mektepleri için hazırlanan 1911 tertibat planına öncül olabilmiştir.

Osmanlı Dönemi'nde uzun seneler boyunca çeşitli şehirlerde deneyimlenerek elde edilen tecrübeler Cumhuriyet Dönemi'ne aktarılmış ve bu tecrübeler yeni eğitim yapılarının planlanmasında etkili olmuştur. Cephe özellikleriyle dönem anlayışını yansıtan eğitim yapıları için süreç içerisinde tip model oluşturma çabaları devam etmiş ve tasarım aşamasında çok sayıda deneme yapılmıştır. Bu bağlamda Ankara Sanayi Mektebi'nin kurgu ve plan şemasının, Cumhuriyet Dönemi'nde inşa edilmiş çeşitli eğitim yapıları için örnek alınıp yorumlandığı dikkat çekmektedir. Ankara Sanayi Mektebi ile kurgu ve plan şeması açısından benzer özellikler taşıyan dönem örnekleri Musiki Muallim Mektebi ${ }^{12}$ (1927-1929), Ankara Yapı Usta Okulu ${ }^{13}$ (1930) ve Bergama Erkek Sanat Okulu'dur ${ }^{14}$ (1953). Bu eğitim yapıları üzerinden söylebiliriz ki; sahip olduğu özelliklerle Ankara Sanayi Mektebi sadece kendi dönemi için değil aynı zamanda farklı dönem ve alanlarda mesleki eğitim hizmeti veren okulların da ihtiyaçlara cevap verebilecek nitelikleri bünyesinde barındıran bir yapı olma özelliğini taşımaktadır (Resim 21-22).
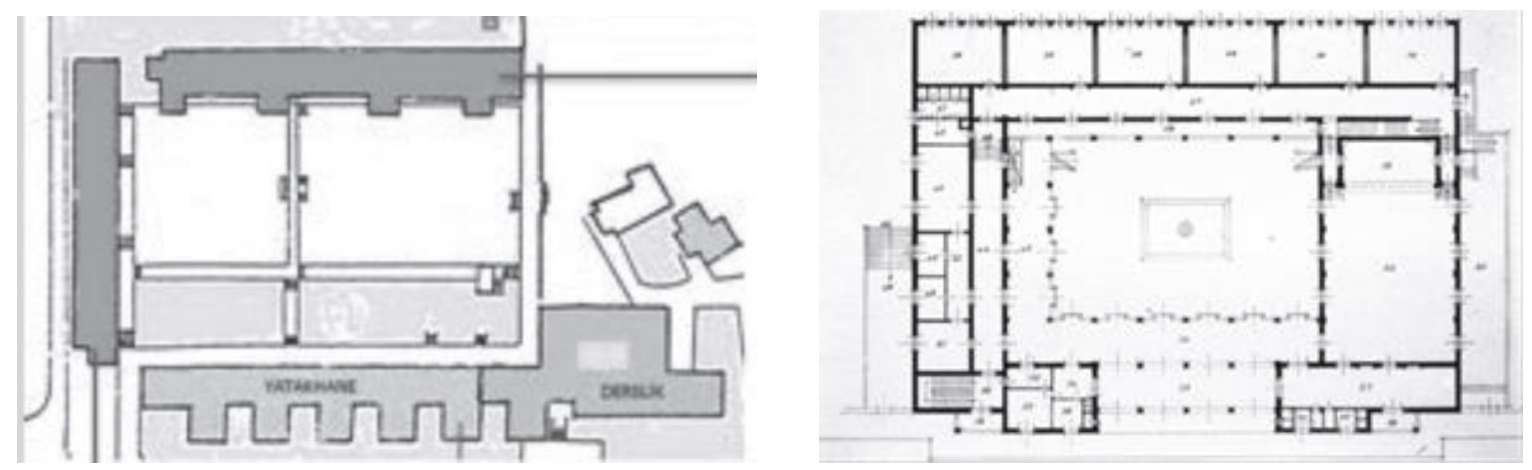

Resim 21-22: Yapı Usta Okulu yerleşim planı (sol), Musiki Muallim Mektebi zemin kat planı (sağ) (Tosun, 2019, s.457; Alpagut, 2019, s.75)

Sonuç olarak; Ankara'nın tarihi hazinelerinden biri olan Ulus semtinde inşa edilen Ankara Sanayi Mektebi, Geç Osmanlı Dönemi’nin eğitim ve mimari alanındaki sözcülüğünü yapan önemli bir mesleki eğitim kurumumuzdur. Modernleşen meslek eğitiminin mimariyi nasıl şekillendirdiğini örnekleyen Ankara Sanayi Mektebi, sadeleştirilmiş neo-Rönesans mimari cephe özellikleriyle Geç Osmanlı Dönemi'nin yeni işlevleri yapıları ile ortak bir mimari biçim diline sahiptir. Sanayi mekteplerinin genel özelliklerini yansıtmasının yanı sıra Ankara Sanayi Mektebi, hem 1911 tertibat planına öncülük yapmış hem de Cumhuriyet Dönemi'nde kurulan bazı meslek okullarına kurgu ve plan şeması açısından örnek olabilmiştir. Ankara kentinin kültürel kimliği içerisinde varolup özgünlüğü büyük ölçüde koruyabilmiş Ankara Sanayi Mektebi'ne odaklanan bu çalışmanın ileriki yıllarda yapılacak araştırmalara katkı sağlayacağını umuyoruz.

\footnotetext{
${ }^{12}$ Musiki Muallim Mektebi, batı müziği alanında bilimsel çalışmaların yapılması ve bunu yaygınlaştıracak öğretmenler ile Cumhurbaşkanlığı Senfoni Orkestrası'nda görev yapacak sanatçıların yetiştirilmesi amacıyla 1924 yılında kurulmuştur. Ersnt Egli’nin tasarımı mektebin mimari özellikleri için bkz. Alpagut, 2019, s. 73-78.

${ }^{13}$ Yapı alanındaki gereksinimleri çağın koşullarına uygun olarak gerçekleştirecek yapı ustalarını yetiştirmeyi amaçlayan Ankara Yapı Usta Okulu'nun mimari özellikleri için bkz. Tosun, 2019, s.445-464.

${ }^{14}$ Bergama Sanat Okulu'nun mimari özellikleri için bkz. Oran, 1952, s. 52-53.
} 


\section{Kaynakça}

Akpolat, M. S. (1991). Fransız kökenli levanten mimar Alexandre Vallaury [Yayımlanmamış doktora tezi]. Hacettepe Üniversitesi Sosyal Bilimler Enstitüsü.

Alpagut, L. (2019). Ankara'da erken Cumhuriyet dönemi'nin medar-1 iftiharı: Musiki Muallim Mektebi. Mimarlık, 56(407), 73-78.

Aslanoğlu, İ. (2010). Erken Cumhuriyet dönemi mimarlı̆̆ 1923-1938. Bilge Kültür Sanat Yayınları.

Altındaş, E.T. (2016). XIX. yüzyılın ikinci yarısında Ankara [Yayımlanmamış doktora tezi]. Ankara Üniversitesi Sosyal Bilimler Enstitüsü.

Günel, G. \& Kılcı, A. (2015). Ankara şehri haritası: eski bir Ankara'yı tanımak. Ankara Araştırmaları Dergisi, 3(1), 78-104. https://dx.doi.org/10.5505/jas.2015.47966

Demirarslan, D. (2014). Batılılaşma/modernleşme dönemi demiryolu politikası ve istasyon binası mimarisi: İzmit ve Hereke tren istasyonları. H. Selvi, B. Çelik (Ed.), Uluslararası Gazi Akça Koca ve Kocaeli tarihi sempozyumu bildirileri içinde (s.1635-1649). Koceli Büyükşehir Belediyesi Yayınları.

Doğan, H., İlhan, S., Bayraktular, E., Hacığlu, F., Ercan, F., Öncü, Z., Akpınar, S., Kılınç, S., Bayraktar, F., Külahçı, Ş.G., Şenol, G.C., Usta, H.E. \& Şahin, Ş. (2012). Cumhuriyet döneminde mesleki ve teknik eğitimde iz bırakan eğitimciler. Ĕ̆itim Araştırmaları Derneği Yayınları.

Draper, J. (1976). The Ecole des Beaux-Arts and the architectural profession in the United States: The case of John Galen Howard. In S. Koskof (Ed.), The Architect: Captes in the History of the Profession (pp.209-237). Oxford University Press.

Erdoğan, A., Günel, G. \& Narince, M. (2008). Cumhuriyet ve başkent Ankara. Ankara Tarihi ve Kültür Dizisi.

İpekoğlu, B. \& Hamamcioğlu, M. (2002). İzmir Mithatpaşa Endüstri Meslek Lisesi yangın sonrası restorasyonu. Mentigan Matbaas1.

Keskin, Ö. (2016). Bozkırda teknik eğitim teşebbüsü: Ankara sanayi mektebi. Çanakkale Araştırmaları Türk Yıllı̆̆gl, 14(20), 65-79. http://dx.doi.org/10.17518/caty.30069

Koç, B. (2014). Osmanlı kent ylllıklarında Ankara: salname-i vilayet-i Ankara. Ankara Sanayi Odas1 Yayınlar1.

Kılıç, A. D. (2006). Vallaurı'nin klasisist cepheleri [Yayımlanmamış yüksek lisans tezi]. İstanbul Teknik Üniversitesi Fen Bilimleri Enstitüsü.

Kuban, D. (2007). Osmanlı mimarisi. Yem Yayınları.

Kutlu, Z. G. (2018). 19.yüzyıldan günümüze İstanbul'da Fransız okul yapıları [Yayımlanmamış doktora tezi]. İstanbul Teknik Üniversitesi Fen Bilimleri Enstitüsü.

Öney, G. (1971). Ankara'da Türk devri dini ve sosyal yapılar. Ankara Üniversitesi Dil Tarih Coğrafya Fakültesi Yayınları.

Oran, S. (1952). Erkek orta sanat okulları ve erkek sanat enstitüleri [Yayımlanmamış yeterlilik tezi]. İstanbul Teknik Üniversitesi Fen Bilimleri Enstitüsü.

Özdemir, R. (1986). XIX. yüzyılın ilk yarısında Ankara. Kültür ve Turizm Bakanlığı Yayınları. 
Tamur, E. (2010). Ankara'da mahalle isimlerine yansıan tarih I. Kebikeç Insan Bilimleri İçin Kaynak Araştırmaları Dergisi, O(29), 57-71.

Tosun, Ç.B. (2019). Ankara yapı usta okulu'nun belleği. P. Ş. Tekinalp, G. G. Alpaslan (Ed.), Kültürel Bellek 2016 içinde (s.445-464). Hacettepe Üniversitesi Yayınları.

Yıldırım, M. A. (2012). II. Meşrutiyet devrinde vilayet sanayi mekteplerini yeniden yapılandırma girişimleri: vilayet sanayi mektepleri tertibatı. Ankara Üniversitesi Dilve

Tarih Coğrafya Fakültesi Tarih Araştırmaları Dergisi, 31(52),135-170. https://doi.org/10.1501/Tarar_0000000524 